\title{
Social mobility in Portugal (1860-1960): operative issues and trends
}

\author{
HELDER ADEGAR FONSECA \\ AND PAULO EDUARDO GUIMARÃES*
}

ABSTRACT. This article presents the results of a study of social mobility in Portugal from the 1860s to the 1960s. Four distinct social contexts were examined by reference to selected criteria, and marriage records were used as the source for data collection and analysis. The HISCO coding scheme was followed to allow comparisons of intergenerational mobility, stratification, and social change. We present the methodological and operative issues inherent in the hermeneutics of the sources used, identifying difficulties in the process of coding arising from the use of a common language to locate individuals in society. We shall offer an opinion on the pace of Portuguese social mobility during the period.

\section{INTRODUCTION}

Social historians must admit to a huge void in our knowledge of occupational and social mobility in Portuguese historiography for the long periods from the Liberal Age (1850-1890), with its industrial and material progress, the age of inconstancy and of the Liberal Crisis (1890-1920s), until the time of Dictatorship (1926-1974), which brought authoritarian stability and the beginning of a golden age of modern economic growth (1950-1973). ${ }^{1}$

After the Civil War (1832-1834), the institutional constraints on capitalist development that persisted from the ancién regime were removed and the country became fully integrated into the world economy led by Britain. Wine and agricultural products, cork, mineral ores, and tinned fish became the major export products, while an internal market developed and

\footnotetext{
* Both of the Research Centre in Political Sciences and International Relations, University of Évora.
} 
reinforced regional variations. Economic development within Portugal was supported by a programme of public works, with a national road and railway network being built between the 1860s and the 1880s. Foreign capital was important to the development of modern organizations, as were entrepreneurs and highly qualified individuals from abroad, many of whom became integrated into the new bourgeois society.

However, the pace of urbanization was slow, with the exception of the cities of Lisbon and Porto, and the rate of illiteracy remained exceptionally high, although that gradually improved during the first half of the twentieth century. Emigration was important too, and it increased during the second half of the nineteenth century, Brazil being the most frequent destination. There were significant regional differences in the intensity of emigrant recruitment until the First World War, with the northern and central coastal provinces and the Atlantic Islands as the major sources of migrants crossing the Atlantic, while in other regions emigration was low or even negligible. For instance, in the same period, the agrarian, mining, and fishing development of Alentejo was attracting both transient and permanent migrants from other regions and countries such as Britain and Spain. $^{2}$

From the First World War to the 1950s, emigration never reached its previous levels, for especially after the 1930s it tended to be limited by institutional constraints imposed by the receiving countries, and emigration to the Portuguese colonies never became a significant alternative to the closing of those foreign destinations. Nevertheless, economic ties with the Empire were reinforced and its economy became a major source of revenue to cover Portugal's chronic trade deficit. ${ }^{3}$

The traditionalist dictatorship of Oliveira Salazar reinforced the social role of the Catholic Church and created a highly regulated economy supported by a nationalist ideology and corporative bureaucracy which after the Second World War sustained a programme of diverse industrial development using a policy of import substitution. The postwar recovery and economic development in the West, or at least in the EEC, created the conditions for a new wave of emigration that spread across the country from the mid-1950s until the crisis of 1973.

In comparison with other Western European countries, for Portugal that long period from the 1860 s to the 1960 s was a century of social and economic change characterized by slow growth in industrialization and population and, in spite of limited urbanization, coastward trends in internal mobility. Different trends in emigration and significant political and institutional changes were part of the same background. ${ }^{4}$

The popular image of Portugal as a backward and peripheral country lacking in opportunities was reinforced by the shift of emigration towards 
'Europe', which totalled 1.3 million people in a decade. In spite of Portugal's negative image, historians have described empirically the formation of a bourgeois elite during the period of its constitutional monarchy, the process of the growth of the 'middle classes', who supported the Republican regime, and, during the New State (Estado Novo), the 'open' recruitment of the Portuguese industrial elite. More recently, Portuguese sociologists have been interested in describing changes in social structure and social mobility patterns since the 1960s, using the Olin Wright analytical framework or Goldthorpe's class scheme. ${ }^{5}$

The main goal of our research project - which is based on the extensive data sample of the Historical Sample of Portuguese Social Mobility (HSPSM) and focuses on parish and civil marriage registers covering four urban and rural contexts ${ }^{6}$ - was to identify and describe the evolution of national and regional patterns in Portuguese social mobility between 1860 and 1960 and to identify the major factors affecting it. We wanted to compare Portuguese mobility patterns with experience elsewhere in Europe and so to participate in the debate about social mobility during the emergence of modern society.

That comparison could not be made properly without using the same occupational coding scheme and methodology as that already in use by other historians in different European contexts. The basic raw data collected as part of the HSPSM were collated by transcribing into datasets the occupational and status titles written in marriage records by parish and administrative authorities. HISCO's occupational and status coding scheme, in its Portuguese version (PACO), was then used to translate those data into useful information to be aggregated and analysed (see the Appendix to this article). ${ }^{7}$

It is a delicate process given that 'the question of classification constitutes the essential starting point for any study of mobility' and if misused it can even inhibit meaningful comparison between societies. ${ }^{8}$ The major problems associated with HISCO's coding, using occupations given in marriage registers across Northern and Western Europe, have been identified and solved to some extent by adding coding options such as 'status', 'relation', or 'product' for particular occupations. However, being a tool to assist both historians and social scientists, 'the Hisco's users have to decide which coding options to use in a given historical and geographical context, ${ }^{9}$

In this article, we shall first present some questions arising from the crucial operation of coding the names of occupations as they were recorded in Portuguese marriage registers and then we shall relate those to the HISCLASS scheme. The aim was to bring to light some of the coding difficulties we found caused by the unreliability of the data available from 
different time periods, the variable accuracy of job descriptions, and differences in the terminology and meanings used to describe an individual's occupation in different social and regional contexts. The last section focuses on tracing the pace of Portuguese social mobility between the $1860 \mathrm{~s}$ and the 1960s, as revealed by the intergenerational transmission of class positions and by absolute mobility.

\section{SOURCES AND REGIONALCONTEXTS}

Until the establishment of a compulsory system of civil registration after the Republican Revolution of October 1910, parish records mentioned the occupations of the parents of the bridal pair only in exceptional cases. Because of that, it is impossible to create meaningful tables of mobility for any specific period or location from data gathered from parish registers before 1911. However, it seems that on some occasions and in some parishes the clergyman did register the occupations of the bridegroom's parents, so the HSPSM began with a systematic collection of data from marriage records from 1911 to 1967. Prior to that period we have a collection of segmented data, gathered from 1860 onward.

The HSPSM database currently includes 16,362 marriage certificates drawn from eight cohorts $(1860-1877 ;$ 1880-1882, 1890-1892; $1900-1902$; 1911-1913; 1925-1927; 1935-1937, and $1955-1957)^{10}$ and collected from four different contexts: in the south of the country, Évora, which was an agrarian, commercial, and administrative region; Setúbal and Barreiro, two new industrial towns; and, by way of contrast, Figueira da Foz, a commercial and fishing port located in the central northern part of Portugal. The censuses taken between 1890 and 1960 corroborate the different evolution of the distribution of the active population by economic sector, Barreiro and Setúbal illustrating patterns of social change induced by industrialization, which were very different from those in Évora and Figueira da Foz (see Table 1). However, in all cases, we found there was significant growth in public administration, liberal professions, and the police and armed forces from the 1930s onward.

During the period 1890-1960, geographical mobility was very high, although Figueira da Foz is an exceptional case. In Barreiro, because of its sustained industrial growth, only 23.6 per cent of bridegrooms between 1911 and 1957 had fathers who had been born there. For Setúbal, the rate was 31.7 per cent for 1900-1957, while agrarian Évora had 51.1 per cent of fathers born outside the municipality. These contrast with Figueira da Foz, which had greater geographical immobility at 81.1 per cent. 


\section{TABLE 1}

Economically active populations in Évora, Setúbal, Barreiro, and Figueira da Foz (1890-1960), by economic sector (\% $)^{a}$

\begin{tabular}{|c|c|c|c|c|c|c|c|c|}
\hline \multirow[b]{2}{*}{ Economic sectors } & \multicolumn{4}{|c|}{ Évora } & \multicolumn{4}{|c|}{ Setúbal } \\
\hline & 1890 & 1911 & 1930 & 1960 & 1890 & 1911 & 1930 & 1960 \\
\hline Agriculture & 44.2 & 49.7 & 44.3 & 41.9 & 41.6 & 30.5 & 13.6 & 13.2 \\
\hline Fishing & 0.0 & 0.0 & 0.0 & 0.1 & 9.0 & 15.2 & 29.5 & 11.7 \\
\hline Mining industries & 0.0 & 0.0 & 0.1 & 0.2 & 0.2 & 0.0 & 0.3 & 0.2 \\
\hline Industry & 17.9 & 19.3 & 15.8 & 20.3 & 16.6 & 26.1 & 27.5 & 42.8 \\
\hline $\begin{array}{l}\text { Transport and } \\
\text { communications }\end{array}$ & 2.3 & 4.4 & 3.9 & 3.5 & 6.8 & 10.0 & 4.2 & 5.0 \\
\hline Trade & 6.1 & 6.3 & 5.1 & 9.2 & 6.4 & 7.7 & 7.0 & 10.7 \\
\hline Police, armed forces & 6.0 & 3.9 & 6.2 & n.a. & 3.0 & 2.1 & 2.2 & n.a. \\
\hline Public administration & 1.1 & 0.6 & 2.8 & 6.6 & 1.2 & 0.6 & 2.1 & 5.2 \\
\hline Liberal professions & 2.5 & 2.2 & 1.5 & 5.4 & 1.3 & 1.1 & 1.5 & 4.4 \\
\hline $\begin{array}{l}\text { Owners } \\
\text { (living off rents) }\end{array}$ & 0.3 & 1.9 & 2.2 & 0.0 & 0.5 & 1.8 & 1.4 & 0.0 \\
\hline Servants & 8.1 & 5.5 & 12.9 & 10.8 & 9.0 & 1.0 & 6.4 & 6.3 \\
\hline Unknown & 11.5 & 6.2 & 5.2 & 1.9 & 4.5 & 3.8 & 4.3 & 0.6 \\
\hline \multirow[t]{2}{*}{$N=$ cases } & 12,628 & 13,854 & 18,463 & 19,527 & 13,982 & 20,790 & 28,016 & 24,366 \\
\hline & \multicolumn{4}{|c|}{ Barreiro } & \multicolumn{4}{|c|}{ Figueira da Foz } \\
\hline Economic sectors & 1890 & 1911 & 1930 & 1960 & 1890 & 1911 & 1930 & 1960 \\
\hline Agriculture & 29.6 & 20.2 & 18.6 & 4.1 & 48.5 & 46.9 & 33.6 & 39.5 \\
\hline Fishing & 0.4 & 1.7 & 0.9 & 0.5 & 6.8 & 8.3 & 10.4 & 8.1 \\
\hline Mining industries & 0.0 & 0.0 & 0.2 & 0.1 & 1.0 & 1.1 & 1.8 & 2.8 \\
\hline Industry & 31.3 & 43.8 & 34.7 & 59.9 & 14.9 & 17.6 & 17.0 & 24.3 \\
\hline $\begin{array}{l}\text { Transport and } \\
\text { communications }\end{array}$ & 20.5 & 18.1 & 20.3 & 12.7 & 2.7 & 2.9 & 4.0 & 4.3 \\
\hline Trade & 4.3 & 5.7 & 4.9 & 9.1 & 4.9 & 9.3 & 5.8 & 7.4 \\
\hline Police, armed forces & 0.4 & 2.5 & 2.4 & n.a. & 0.5 & 1.1 & 2.0 & n.a. \\
\hline Public administration & 0.5 & 1.2 & 1.8 & 3.8 & 0.9 & 0.5 & 1.5 & 3.5 \\
\hline Liberal professions & 1.4 & 1.1 & 0.5 & 3.8 & 0.9 & 1.3 & 0.9 & 2.9 \\
\hline $\begin{array}{l}\text { Owners } \\
\text { (living off rents) }\end{array}$ & 0.5 & 1.7 & 1.0 & 0.0 & 1.0 & 4.9 & 3.1 & 0.0 \\
\hline Servants & 7.9 & 0.9 & 5.2 & 5.1 & 9.6 & 1.4 & 14.2 & 6.8 \\
\hline Unknown & 3.4 & 3.2 & 9.4 & 0.8 & 8.3 & 4.6 & 5.7 & 0.3 \\
\hline$N=$ cases & 2,272 & 5,345 & 12,046 & 13,991 & 20,106 & 19,950 & 28,223 & 20,971 \\
\hline
\end{tabular}

${ }^{a}$ Data from the 1930 and 1960 censuses were aggregated based on the criteria used in 1890 and $1911 ;$ n.a. $=$ data not available.

Sources: Census of Portuguese Population, 1890-1960 (Lisbon, 1891-1960). 
Even if we can agree that the HSPSM does not currently represent the whole range of social variation throughout the country, we are at any rate sure that it will bring new light to the study of Portuguese social structure and make it possible to identify significant patterns of social mobility.

The first problem with the post-1911 civil registration records relates to their coverage. Not all marriage records can be used for the purpose of mobility tables for the simple reason that in many cases we have no occupation or status registered for the bridal pair, the bridegroom's parents, or the father of the bride. The main reasons for that are, in order of importance, the death of a parent by the time of a child's marriage, cases of illegitimacy, and child abandonment. From a few of the available references we can add that dissolution of family ties is another reason for omission of that information. Altogether, there is a great deal of data missing, while the extent of that omission varies according to local context. After second marriages were purged from the dataset, only 36.6 per cent of registers recorded the occupation of both father and son and 38.3 per cent recorded the occupations of son and father-in-law.

If such 'valid observations' are not socially random, the value of the whole sample will necessarily be threatened. Considering the hypothesis that there were significant differences in life expectancy among various occupations and classes, and that illegitimacy would probably affect social groups unequally, the records with missing data would affect mainly the lower classes. Therefore the social and occupational structure built upon those data would be distorted by the under-representation of groups such as workers and semi-skilled workers, tending to inflate ratios. Fortunately, that does not seem to be the case here. Comparison of average age of fiancés recorded in all the registers at the time of their first marriage, and in all the period cohorts considered, has shown that that average age is always higher than that of the 'valid sample'. This can be explained simply by the fact that the younger a bridegroom was, the more likely it was that both his parents would be alive. However, in each period cohort there are persistent and coherent 'regional' differences and significant variations in the average age at first marriage for men and women alike.

On the other hand, when we use the HISCLASS scheme to aggregate the stated occupations of bridegrooms, we find no significant differences in the weight of each class between the 'valid sample' and the total of marriage registers. Given that the difference between their relative value is less than 2 per cent for almost all classes, we may safely assume that the missing occupational data is contingent, and so does not compromise the validity of the sample for the chosen context. 


\section{SOCIAL LANGUAGE AND OCCUPATIONAL CODING}

The accuracy of occupational titles found in Portuguese civil registers to identify individuals in society has recently been the subject of scrutiny. ${ }^{11}$ Ambiguities are amplified when we need to manipulate the occupational data of parish registers, and we have identified five main difficulties in the use of Portuguese historical occupational titles: the intense concentration on generic titles used before industrial times; the ambiguous, amorphous, and laconic terms used; the occupational and social homonymy; the occupational and social synonymy; and the invisibility of the actors. Such initial problems are often seen in other national contexts, in particular when the purpose is to chart patterns of social structure or mobility from nineteenth- and early-twentieth-century data. ${ }^{12}$

From the 1860 s to the 1960 s, the distribution of individuals by occupation and status is usually concentrated in a few generic titles, which clearly shows the low technological sophistication of the Portuguese economy and the preponderance of individuals with low professional qualifications: 60 per cent of individuals present in the marriage registers are distributed among 15 generic 'professions'. ${ }^{13}$

On the other hand, 92 per cent of the occupational titles used had ten individuals or fewer associated with them. In fact, 65.6 per cent of the titles were applied to only one individual. The reason for that, in many cases, was the need to locate an individual socially by reference to his occupation with its recognized rank and status in a specific organization. As a result of that, for this study 3,430 occupational and status titles were 'squeezed' into 564 HISCO codes, so that in sum we have, on the one hand, a long list of descriptions of occupations but with only a few individual cases and, on the other hand, a small number of cases with which to describe the social positions of the majority of the population.

At first sight, the quality of the information recorded in marriage registers might appear to jeopardize the feasibility of an intergenerational mobility analysis. In Évora, for instance, we would expect a clear distinction between 'day-labourer' (jornaleiro) or 'rural worker' (trabalhador rural) and 'industrial worker' (operário). But there is no such distinction. The percentage of labourers whom we can identify in HSPSM as working in agriculture is exceptionally low, and only by adding their number to those described as 'workers' could we approach the numbers given in the official census to obtain the percentage of people working in agriculture.

After the 1930s the specification of workers as 'rural' was exceptional, and in any case we are not sure who was working in agriculture and who was not, unless we assume that these three expressions - 'day-labourer', 
'rural worker', and 'industrial worker' - are synonymous. In fact, 'rural workers' were often employed on public works or in rural industries such as olive-oil pressing and construction, or they worked at whatever was available. On the other hand, even workers living in 'urban parishes' often worked in agriculture.

Moreover, the residence criterion for distinguishing rural from urban workers is not accurate for the simple reason that modern industry often chose to locate itself in rural areas just outside cities. The labour market of Alentejo was beneficial to such flexibility: at the beginning of the twentieth century, "parallel to the full-time farmhand, there was also an important segment of the workforce who provided a significant portion of an alien, migrant contingent of day-labourers ... who were farmhands and miners, porters or "jacks-of-all-trades". ${ }^{14}$

The same thing happened in major heavy industries. In the industrial and railway centre of Barreiro, the term 'worker' (trabalhador) was applied to 'a numerous, itinerant, and unqualified contingent of workers' by the Companhia União Fabril (CUF), a large chemical company established in 1907 which usually recruited from among poorly educated newcomers to the town, mainly from rural areas. In 1908, 1917, 1940, and 1950 the company employed 100, 2,000, 6,000, and then 10,000 assorted 'workers' respectively. Such employees generally did a wide range of more or less thankless tasks, with little security, giving them an uncertain future. The short professional and social distance between the different groups of operários (industrial workers), and in particular the process of the decline of the 'worker aristocracy', brought them very close to the 'rural workers'. ${ }^{15}$

Another problem relates to professional and social disqualification to technological and organizational change. The phenomenon of 'downward professional mobility' occurred among other elements of the 'artisan intelligentsia', such as barrel-makers and glass-makers and the cork-makers, welders, and tinned-fish workers. ${ }^{16}$ But other 'artisan' professions had a social trajectory in the opposite, upward, direction. Chemists are a good example. Until about 1837 the profession had been organized as a craft, with six years of practical learning in a chemist's shop (botica) required, and from then until the beginning of the twentieth century practical learning in different boticas was certified by academic schools. Subsequently, chemists required a university education to enter the profession, and thereafter they developed their pharmaceutical skills at work in chemist's shops named farmácia. ${ }^{17}$

Something similar happened with other independent traditional crafts: from the 1920s onward the term 'industrial' gained widespread acceptance, fiscally and electorally, to refer to people who some years earlier 
would have been identified by their craft, such as 'barber', 'baker', 'blacksmith', 'hotel-keeper', or 'photographer'. A record for Setúbal in 1937 says quite clearly 'profession: barber (barber's industrial)' ; another record from the same year refers to 'barber's industrial (at the moment in service as a soldier)'.

The authoritarian institutionalization of corporative associations after 1933, which forced a segregation of managers from workers, had some influence on the need for social distinction, given that earlier there had been more than 300 'mixed associations' spread across the country, almost a third of all workers' and managers' associations. In Évora, for instance, between the 1930s and the 1950s the numbers of individuals referred to as 'industrials' in electoral registers boomed, without any visible sign of equivalent economic change. ${ }^{18}$ This occupational and social transition occurred generally during the first three decades of the twentieth century.

A number of coding problems have already been identified, but we evolved some operational concepts to deal with specific problems found in our sources. Because of regional linguistic peculiarities we have uncovered cases of social homonymy, which is when the same name for an occupation refers to jobs with different statuses. A typical case is the title 'farmer' (lavrador). In the modern period, the term lavrador first of all has an 'occupational basis', as a current activity and second, in both northern and southern Portugal, it embodies an 'economic and social status', a social condition, a sociological attribute which implies local or regional social notoriety and a higher position, although not necessarily at the top, in the "hierarchy of social and occupational categories related to agrarian activity'. However, it is necessary to separate the different patterns of agricultural farm organization that the term covered. During this period, in the Atlantic north the lavrador was head of a family farm which employed family members and casual day-labourers. But in the vineyards of the Douro in the north-east (producing port wine), in the rice-growing fields of Mondego (in the centre), and on the plains of Ribatejo and Alentejo in the south (the regions of latifundia), both specialized and diversified farmers were landowners (or tenants) of large estates, leading agricultural capitalists (which included running industrial activities upstream of the agricultural harvest) employing hundreds, sometimes thousands of men at harvest time. Usually they were actively entwined with other business and social interests.

In terms of codification and occupational hierarchy it is therefore essential to establish a distinction between the two types of farmer. For farmers of regions featuring large-scale agricultural exploitation, such as Évora (Alentejo), who managed a mass of permanent and temporary 
workers and employees, including industrial workers, we use the general HISCO code for independent farmers, but in the HISCLASS scheme we have positioned them towards the top, together with higher managers. ${ }^{19}$

Empirical historical knowledge of local specificity is very important for identifying instances of false or apparent social synonymy, such as in Setúbal 'fisherman' (pescador) or 'seaman' (maritimo). At the beginning of the twentieth century the title 'fisherman' was applied to individuals who fished in the Sado's estuary or near the coast, while 'seaman' usually referred to sardine fishermen and implied an activity that had a capitalist organization.

Seamen worked for a company (cerco), while fishermen usually had their own small enterprise, invariably family-based. Many fishermen owned their own boat, while their wives looked after the small-scale trading of their catch. They usually came from the fishing community of Murtusa, in the Aveiro district on the northern coast, and had their own 'class' association and religious feasts. Although the group included a few 'seamen', the large majority came from the parish of Carmo da Fuzeta (Olhão) in the Algarve.

The 'class association' of the seamen was the largest and most powerful in the town during the First Republic (1910-1926), when it had a strong libertarian and socialist culture. A journalist from Lisbon, visiting the town at that time, was astonished by the fact that, despite both groups having similar levels of income, their social behaviour was completely different. The fishermen were described as displaying the morals and attitudes of the bourgeoisie: they were prudent and honest, conservative and religious in their values, and had adopted a parsimonious way of living. The seamen, by contrast, at the end of each fishing voyage spent all the money they had made and, having a liking for dressing well, would preen themselves and generally show off. The marriage registers from Setúbal reflect that accurately. It is of course suggestive that the administrative officials themselves distinguished between the two occupational titles, and the proportion of the two occupations in the sample replicates what we know from other sources. ${ }^{20}$

Up to this point, we have shown the 'logic' underlying the use of occupational titles in parish and civil registers, which emphasize status and rank in spite of their low degree of specification. They are a poor source for reconstituting information about occupations within a branch of economic activity, although they reflect with precision the 'class' (as it was understood) of each individual.

Finally, we should consider the partial or total 'invisibility' of foreigners, who usually occupied specialized, technical, and top management or senior professional positions in foreign companies, operating in major 
export sectors, often in large industries or transport. The mining industries, the cork industry in the south, and the tinned-fish industry in Setúbal were social spaces where such people, now scarcely if at all visible to the historian, were highly active in the past.

We have, then, illustrated some of the problems that have emerged from the analysis of occupational titles found in Portuguese historical sources from the nineteenth and twentieth centuries. We have focused on those for which we have found solutions, but we freely admit that we have omitted others, such as the complicated question of the use of the term proprietário (owner), a status attribute covering a variety of social locations. Nevertheless, we believe that in this phase of our work we can proceed without needing to solve so 'durable' a difficulty.

\section{PORTUGUESE SOCIETY AND SOCIAL MOBILITY (1 $860-1960)$}

In a rare approach to looking at nineteenth-century Portuguese society, Rui Cascão designed an outflow matrix of social mobility for the town of Figueira da Foz and for Buarcos, the neighbouring fishing village, both of which lie along the country's central Atlantic coast. He concludes, in the first place, that the general trend between 1860 and 1910 was towards 'self-recruitment' (reproduction) of social groups; second, that mobility was higher at the top of the social structure than at the bottom (for example among fishermen and unskilled workers), particularly so among the fishing community, where the immobility rate exceeded 90 per cent; and last, that intermediate social groups, such as craftsmen and other skilled workers, fulfilled a 'stabilizing and distributive function' both in upward and downward individual circulation. ${ }^{21}$

From the second half of the nineteenth century there is plenty of empirical evidence to show the existence of strong occupational and social transmission in several strata of Portuguese society. It can be found first in the families of large farmers, landlords, and traders, who were the main elite group in the south, which was dominated by large estates. Members of that group reorganized themselves by means of the social promotion allowed by the formation of a 'census power society' which came with the triumph of the Liberal Revolution (1834) and by recourse to marriage strategies and alliances, which became an important element of cohesion and social reproduction.

In the process, the traditional regionally based aristocracy also had an important role. ${ }^{22}$ We can find the same pattern at the top of the 'social pyramid' in the rural milieu of Minho province in the north of the country, composed of 'landowners' (i.e. farmers) - although tight and severe mechanisms of marriage control and inheritance systems, often 
associated with emigration, suggest more strongly the reproduction of social position than occupational transmission across generations. It was from among the sons of the landowner-farmers of Minho province that the merchants of the country's main markets had been recruited since the eighteenth century, ${ }^{23}$ and it was from among their sons and the sons of the traders that a significant proportion of the first industrial workforce was recruited to man the textile factories as they spread across rural areas of northern Portugal, becoming part of the Portuguese industrial elite in the first era of industrialization, the last quarter of the nineteenth century. ${ }^{24}$

Change of occupation associated with upward social reproduction can be found among the sons of those groups and within the middle classes generally, who used higher education as a channel to gain access to the open positions offered by the state bureaucracy. In fact, the number of office employees doubled between 1850 and 1890 ; they aspired to join the liberal administrative elite, half of which was recruited from the region of Lisbon. ${ }^{25}$

At the bottom of society, too, we find a strong picture of social selfreproduction among day-labourers and miners in the south of the country and among workers, journeymen, and servants in Minho. Without any formal education or any resources to cross the Atlantic, both might meet on the plains of Alentejo, where they could always find temporary work on large commercial agricultural estates, in public works, or, perhaps less easily, in mining and other local industries. ${ }^{26}$ During the period 1860-1890 the mining communities of Aljustrel and Saint Domingos received a strong influx of regional migrants - mainly rural workers and sharecroppers - which accounted for 85 to 90 per cent of their workforce, with 5 to 10 per cent coming from the Algarve.

Oral testimonies and local reminiscences present us with an image of a world apart, dominated by social self-recruitment. Until 1950 'it is possible to say that the social mobility of the miners was most insignificant' and among mill personnel (crafts and specialized workers) and employees of the administration, too, occupations would 'pass from fathers to sons'. At the top, a foreign elite ruled, of British, Belgian, or French origin. They were the senior managers, engineers, and technicians, but they lived and died apart from the locals. ${ }^{27}$

In spite of such examples, Portuguese society was changing. New occupational groups appeared such as railwaymen, who were highly segmented and hierarchical, and who became a 'labour aristocracy', ${ }^{28}$ while in the middle range of the social pyramid some occupational groups began to take quite distinctive paths. While pharmacists and workers in some other crafts saw an increasing rise in their social value, 


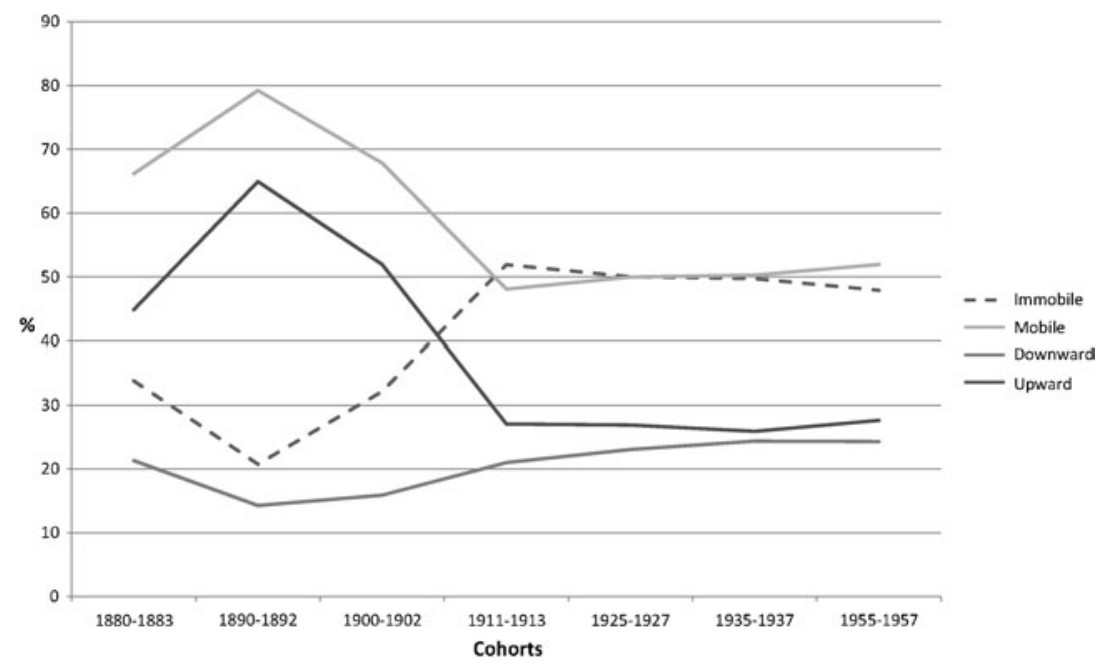

Figure 1. Index of total intergenerational mobility in five representative Portuguese contexts, 1880-1957. (Source: Historical Sample of Portuguese Social Mobility (HSPSM).)

other groups coming from the craft intelligentsia, such as cork stop makers and miners, gradually became simple wage workers and as a result declined socially. Some of them tried to resist the trend by using trade unions as tools for closed-shop strategies, as did typographers and glass-makers from Marinha Grande. They were attempting to save the prestige of their craft through a monopoly of their practical skills and through closing access to their craft by using their unions for the purpose, much as endogamy was used as a reproductive strategy. We find similar behaviour in other contexts of industrial and qualified work, at more advanced stages of Portuguese industrialization, for example among metalworkers at CUF (1907-1976), the country's largest industrial company. ${ }^{29}$

Figure 1 shows the evolution of the total intergenerational mobility rate (TIMR) in the HSPSM between 1880 and 1957, divided into seven cohorts and calculated by aggregating the twelve 'HISCLASSes' into seven (see Appendix Tables 2-5), for analytical purposes. The data include all first marriages for which the occupation of the bridegroom and his parents was given in the civil records for our four social contexts (évora, Setúbal, Barreiro, and Figueira da Foz; see above). However, we have considered only Évora and Figueira da Foz from before 1911, since for those places parish register data were more consistent.

We can see that total mobility increased slowly after the Republican Revolution of 1910 , from 48 to 52 per cent of the total, being more static 
TABLE 2

Index of total intergenerational mobility in Évora, Figueira da Foz, Setúbal, and Barreiro $(1860-1957)^{a}$

\begin{tabular}{|c|c|c|c|c|c|c|c|c|c|c|c|c|}
\hline \multirow[b]{2}{*}{ Cohorts } & \multicolumn{3}{|c|}{ Évora } & \multicolumn{3}{|c|}{ Figueira da Foz } & \multicolumn{3}{|c|}{ Setúbal } & \multicolumn{3}{|c|}{ Barreiro } \\
\hline & Mob. & Down & $U p$ & Mob. & Down & $U p$ & Mob. & Down & $U p$ & Mob. & Down & $U p$ \\
\hline $1860-1877$ & 34.8 & 16.5 & 18.3 & n.a. & n.a. & n.a. & n.a. & n.a. & n.a. & n.a. & n.a. & n.a. \\
\hline $1880-1882$ & 43.6 & 29.1 & 14.5 & 82.5 & 15.0 & 67.5 & n.a. & n.a. & n.a. & n.a. & n.a. & n.a. \\
\hline $1900-1902$ & 54.7 & 40.6 & 14.1 & 81.1 & 3.8 & 77.3 & 57.5 & 16.1 & 41.4 & n.a. & n.a. & n.a \\
\hline 1911-1913 & 46.5 & 21.1 & 25.4 & 48.1 & 19.8 & 28.3 & 45.2 & 18.0 & 27.2 & 58.7 & 28.6 & 30.1 \\
\hline $1925-1927$ & 51.8 & 26.2 & 25.6 & 49.5 & 22.3 & 27.1 & 44.2 & 17.4 & 26.7 & 56.4 & 23.9 & 32.5 \\
\hline $1935-1937$ & 47.7 & 22.5 & 25.1 & 55.4 & 27.1 & 28.3 & 39.0 & 18.0 & 21.0 & $\mathbf{5 7 . 5}$ & 24.2 & 33.3 \\
\hline 1955-1957 & 44.2 & 15.2 & 29.0 & 60.5 & 29.8 & 30.6 & 60.0 & 23.7 & 27.3 & 63.3 & 34.6 & 28.7 \\
\hline
\end{tabular}

${ }^{a}$ Mob. $=$ mobility: the number of men in a class different from that of their fathers, as a percentage of the total; down=downward mobility: the number of men in a class inferior to that of their fathers, as a percentage of the total; up=upward mobility: the number of men in a class superior to that of their fathers, as a percentage of the total; n.a.=data not available.

Source: Historical Sample of Portuguese Social Mobility (HSPSM).

among the 1920s and 1950s cohorts. During that period, the index of upward mobility stayed constant as an almost flat line, but it was always higher than downward mobility. From the 1890s there was a trend of constant growth in downward mobility, although never more than 10 per cent over seven decades, and it never quite reached 24 per cent.

Those figures contrast starkly with data from the 1880 s to the Republican Revolution. The numbers reveal a period of great social mobility and of the highest upward mobility, and then a deep decline after the 1890 s. It might be thought that our effort to form a picture of social mobility in Portugal before 1911 is influenced by the quality of the sample, or by the fact that we have here data from just Evora and Figueira da Foz. The data from Figueira da Foz did indeed influence the overall picture of the period, and to assess that influence we need to compare the different social contexts.

Figueira da Foz had an exceptional index of social mobility, dominated by an upward trend that can be explained by the development of crafts, small industries, and retailers in a context of social change, economic growth, and diversification (see Table 2). The TIMR increased in Évora from the 1860s until the twentieth century, but it was dominated by downward mobility, until from the 1920s the trend reversed again up to the 1950s, when upward mobility increased on the eve of the First World 
TABLE 3

Correlation of total intergenerational mobility rate (TIMR) and total upward mobility between Évora, Figueira da Foz, Setúbal, and Barreiro

\begin{tabular}{lcccccc}
\hline \hline & Set-É $v$, & Set-Bar, & $\dot{E} v$-Foz, & Foz-Set, & Foz-Bar, & Bar-Év, \\
& $1900-1957$ & $1911-1957$ & $1880-1957$ & $1900-1957$ & $1911-1957$ & $1911-1957$ \\
\hline Upward mobility & -0.78 & 0.92 & -0.94 & 0.70 & 0.47 & -0.95 \\
TIMR & 0.40 & 0.82 & 0.05 & 0.83 & 0.76 & -0.95 \\
\hline \hline
\end{tabular}

Notes: Év =Évora $;$ Foz = Figueira da Foz $;$ Set $=$ Setúbal $;$ Bar $=$ Barreiro.

Source: Historical Sample of Portuguese Social Mobility (HSPSM).

War, and from the 1930s. In contrast, the TIMR in Figueira da Foz increased constantly after 1911 .

The highest TIMR after 1911 was in Barreiro, where upward mobility was dominant until the late 1930s. Setúbal had a lower TIMR, which had diminished steadily from the beginning of the twentieth century and continued to do so up to the eve of the Second World War. Upward mobility followed a similar trend there. Considering all contexts then, we can see that the pace of TIM increased during the 1950s, but with Évora as a remarkable exception.

Table 3 summarizes the statistical correlation among those social contexts, showing the strong 'negative' relationship between the capitalist agrarian and industrial contexts on the one hand, and the strong 'positive' relationship among industrial contexts.

\section{THE FIRST HALF OF THE TWENTIETH CENTURY:TWO ERAS IN PORTUGUESE SOCIAL MOBILITY?}

In a piece about the 'social structure of the Portuguese people' published in 1953, a well-known physician and criminal anthropologist argued that in Portuguese society during that period there was upward social mobility 'from one class to another' and that it occurred 'very, very often'. ${ }^{30}$ So class differences, and variations in patrimonies, had a tendency to diminish. The author considered that a good thing, since average income was not decreasing. The quantitative data available confirm an increase in occupational and social mobility during the first half of the twentieth century. However, that thesis needs to be qualified.

For the period 1911 to 1957 , we must distinguish two phases. The first, up to the end of the 1930s, saw very low TIMR growth. Although small, a greater percentage of individuals climbed the hierarchy than descended it, with the exception of Alentejo (Évora) (see Figure 1 and Table 2). In the 
second phase, from 1935 to 1957, the TIMR increased and social mobility rose, although the industrial town of Barreiro appears as a remarkable exception to that trend.

The predominantly upward increase in TIMR developed over a period which saw growth in the supply of labour, an evolution associated with the persistence of high birth rates, a decrease in emigration, and the beginning of a long phase of decline in demand for agricultural workers (1940-1990), along with the greater presence of the liberal professions and white-collar jobs in public administration (1930-1960) and steady growth in industrial jobs (1930-1970s). ${ }^{31}$

The occupational classes with higher and more stable rates of immobility in our sample during this long period were drawn from the lower working classes: the average immobility rate for them was 61.0 per cent from the 1880s to 1957; of that group about 60 per cent were 'unskilled workers' and about 40 per cent 'lower-skilled'. However, from 1911 recruitment from among those 'classes' declined, reaching 41 per cent in 1957. In those groups, transmission of an occupation between father and son happened more often and was more persistent than among 'farmers', whose sons could more easily find other professional destinies. However, in 1955-1957, the groups of 'foremen', 'skilled workers', and 'lower-skilled workers' all became more receptive to people coming from other origins. Recruitment from among 'managers, professionals, and sales' - in other words among non-manual classes - became higher in general, with an average immobility rate of 61.0 per cent between the 1880 s and 1957. However, the trend was towards an increase in immobility, reaching 68 per cent in the last period cohort.

Remarkable too is the variation in the immobility rate among 'higher managers and higher professionals', which was 42.3 per cent in 1911-1913, then increased in the two interwar cohorts before returning to its previous level. That trend confirms that the policy of social openness in higher education, limited during the Liberal Republic (1910-1926), was followed by a restrictive policy that promoted selection based on 'hidden criteria of selection on social and economic bases' right from the first years of the Military Dictatorship (1926-1933) and then the Estado Novo (1933-1974). ${ }^{32}$

Between 1930 and 1960, the number of university students tripled, allowing the sons of the 'upper-middle class' and 'upper class' greater access to education, ${ }^{33}$ although the daughters of some social groups also went to university. Between 1952 and 1954, only 8.8 to 10 per cent of the sons of workers, employees, the lower ranks of the armed forces, or civil servants - 77 per cent of the entire active male population - went to university. At the beginning of the 1960s between them the 'higher group' 
and the 'upper-middle group', who represented just 3.8 per cent and 6.9 per cent of Portuguese families respectively, took 85 per cent of university places, or 86.1 per cent when considering only female students. ${ }^{34}$

From the 1930s to the 1950s, the high degree of exclusivity of the 'higher professions' and 'higher management' in public administration ${ }^{35}$ contrasts with the opening of industry to small and medium-sized entrepreneurs. In Alentejo, where they were an emergent group, industrialists were recruited not only from ancient industries but from among traders, craftsmen, and, on a smaller scale, farmers. Even so, many of them were newcomers to industry and the economic life of the region, having come from other parts of the country. ${ }^{36}$

In 1942 in the central and northern coastal areas access to the management classes in industry was difficult, but the "bosses who presently exist in trade or industry usually came from among former workers who, thanks to an epoch more favourable to the rapid growth of their business, had the luck to obtain positions of leadership' ${ }^{37}$ Such a relative openness of the entrepreneurial sector is clear among the leaders of the major Portuguese industrial firms, in which 53 per cent were owner-managers. ${ }^{38}$

Finally, we must consider in this description the 'foremen and mediumskilled workers' and 'lower-skilled workers'. In 1911-1933, 68 per cent of the people classified in the first group came from other occupations, while in the late 1950s self-recruitment was at 32 per cent, the same rate as in the 1930s, a rate of self-recruitment similar to that of the second group. The social origins of those 'open' intermediate 'classes' were rather differentiated, they being recruited from three main groups: lower-skilled workers, unskilled workers, and lower clerical and sales workers. ${ }^{39}$ The data confirm the greater openness of specialized work at the moment Portuguese industrialization took off. ${ }^{40}$

Analysis of relative mobility from 1911 to 1957 in all four social contexts, using our seven classes, confirms the general pace of social mobility described. Using odds ratios to calculate relative mobility tables, we tested four simple models, considering (a) the hypothesis of the absence of any clear relationship in the transmission of class position from father to son (the 'independence model'); (b) the possibility that the class of father and of son are independent except for diagonal cells (the "quasi-perfect mobility model'); (c) the hypothesis that social classes were immobile 'to some extent' during this period; and (d) Goodman's 'quasi-uniform association model', which predicts that mobility takes the form of mobility between closer social classes. ${ }^{41}$

The results have shown that the 'independence model' must be rejected, meaning that some pattern of relationship in the transmission of class from father to son is present in our sample (see Table 4). On the other 
T A B LE 4

Simple models of relative mobility in Portugal 1911-1957

\begin{tabular}{lcccccc}
\hline \hline & Chi-square & $L^{2}$ & $D f$ & $D i$ & BIC $\left(L^{2}\right)$ & AIC $\left(L^{2}\right)$ \\
\hline Independence model & 73.97 & 67.45 & 36 & 0.41 & -78.1 & -4.55 \\
Quasi-perfect & 17.36 & 21.81 & 29 & 0.15 & -9543 & -36.18 \\
$\quad$ mobility model & & & & & & \\
Inheritance model & 20.65 & 25.23 & 29 & 0.19 & -92.01 & -32.76 \\
Quasi-uniform & 6.33 & 7.8 & 18 & 0.08 & -64.88 & -28.11 \\
$\quad$ association model & & & & & & \\
\hline \hline
\end{tabular}

${ }^{a} \mathrm{Df}=$ Degrees of freedom; $\mathrm{Di}=$ Dissimilarity index; $\mathrm{BIC}=$ Bayesian Information Criteria; $\mathrm{AIC}=$ Akaike Information Criteria.

Source: Historical Sample of Portuguese Social Mobility (HSPSM). (data from Évora, Setúbal, Barreiro, and Figueira da Foz).

hand, the 'quasi-perfect mobility model' fits better than the 'inheritance model', which indicates that social mobility was stronger than transmission. However, it is the last model (having a lower Bayesian Information Criteria (BIC) and $L^{2}$ ) which best fits the data, meaning that mobility did exist but was generally between near-neighbour classes.

\section{CONCLUSION}

In spite of the difficulties presented by the Portuguese sources, the use of the HISCO and HISCLASS scheme is fruitful for identifying social structures and mobility patterns and for building up data to be compared with other European contexts. In marriage registers from 1911 to 1957, occupation titles of individuals were often used to point to status and rank, and to emphasize the stability of their link to an organization. So for that period locating the social position of individuals through their "profession' often jeopardizes our understanding of the precise nature of their occupations. A detailed knowledge of the social and professional regional contexts is required to locate individuals according to the HISCLASS scheme.

Using our analytical framework it was possible to build up a general picture of the evolution of intergenerational social mobility in Portugal from 1860 to 1960 , taking into account regional variations. We have shown that there was an initial period, from the 1860 s to the first decade of the 1900s, with high contrasts in the pattern of the TIMR in the two contexts for which we have significant information. We can conclude that the increase in the TIMR at the beginning of the twentieth century was associated mainly with a downward trend in mobility since 
the 1860s. However, in Figueira da Foz the high TIMR was associated with the highest rate of upward mobility since the 1880s; this declined after 1911. From the 1880s to 1917, the tinned-fish industry, cork manufacturing, and the chemical industry 'took off' in Setúbal and Barreiro. Unfortunately, we cannot analyse this period in depth and get a general picture since the regional contrasts were so high. On the other hand, our analysis reinforces the need for the study of mobility within a country, to establish common patterns, as much as between countries and regions.

In the 1930s, a second phase began, characterized by slow growth in social mobility. The current literature on the period has emphasized the divisions across the peasantry, horizontal mobility between the rural and urban proletariats, and reconstitution of the traditional petite bourgeoisie into a class dependent on the salary regime of the third sector (services and trade). ${ }^{42}$ We still do not know the full extent of the flux, but analysis suggests the existence of significant mobility among manual workers, especially in the industrial sector; the relative opening up of mainly small and medium-sized entrepreneurial classes; and the reinforcement of the mechanism of social reproduction among the liberal professions and within the class of state administrators. Those indicators suggest few changes in the configuration of Portugal's social structure until the 1950s, there remaining a strong presence of the traditional bourgeoisie, based in small firms.

In sum, Portuguese data show that industrialization and urbanization do increase geographical and social mobility, but the same pattern can be found in regions such as Évora, where large capitalist farming organizations dominated and the growth of urbanization was low. The trend to increased upward mobility in Évora from the 1860s contrasts with what happened in the industrial town of Barreiro during the first half of the twentieth century. In spite of regional differences, a common pattern can be found in Portuguese society during the first half of the twentieth century, characterized by the slow growth of social mobility, which is to say upward or downward mobility within neighbouring classes: in other words a pattern in the social configuration of a polarized society in the top and in the bottom ranks in which the intermediate classes took a (limited) redistributive role.

Considering the debate about the evolution of social mobility in modern societies, the 'Portuguese case' does show a general trend towards an increase in the TIMR during the period $1911-1957 .{ }^{43}$ However, upward intergenerational mobility was slight, non-linear during that time, and not clearly related to either industrial or emigration contexts. On the other hand, given that educational opportunities for the lower classes remained limited, the growth of the public administration (the 
'bureaucracy') and of state security forces must be considered 'structural' channels that created individual opportunities to 'escape' from 'manual work'. Thus, privileged access to higher education and, at the same time, technological development supported the growth of 'liberal and highly qualified professions', which tended to encourage mobility within the upper classes by guaranteeing them commanding positions in the state administration, the armed forces, or the larger industrial organizations. Overall, analysis of relative mobility from father to son has revealed a prevailing pattern of mobility among neighbouring classes.

A P PENDIX

Appendix TaBle 1

Total intergenerational mobility in Portugal, 1880-1957 (\%)

\begin{tabular}{lcccc}
\hline \hline Portugal & Immobile & Mobile & Downward & Upward \\
\hline $1880-1883^{a}$ & 33.8 & 66.2 & 21.3 & 44.9 \\
$1890-1892^{a}$ & 20.8 & 79.2 & 14.3 & 64.9 \\
$1900-1902^{a}$ & 32.2 & 67.8 & 15.9 & 51.9 \\
$1911-1913$ & 51.9 & 48.1 & 21.0 & 27.1 \\
$1925-1927$ & 50.0 & 50.0 & 23.1 & 26.9 \\
$1935-1937$ & 49.7 & 50.3 & 24.4 & 25.9 \\
$1955-1957$ & 47.9 & 51.9 & 24.3 & 27.6 \\
\hline \hline
\end{tabular}

a Relates only to data for Évora and Figueira da Foz.

Source: Historical Sample of Portuguese Social Mobility (HSPSM).

Appendix Table 2

Intergenerational mobility in Évora, 1860-1957: a comparison of the social classes of fathers and sons at first marriage (relative and absolute values)

\begin{tabular}{lrrrrrrrrc}
\hline \hline $\begin{array}{l}\text { Social class } \\
\text { of the father } \\
1860-1877\end{array}$ & \multicolumn{8}{c}{ Social class of the son } \\
\cline { 2 - 9 } & $1+2$ & $3+4+5$ & $6+7$ & 8 & 9 & 11 & $10+12$ & Total N \\
\hline Higher managers, & & & & & & & & \\
higher professionals, & 37.5 & 50.0 & 0.0 & 0.0 & 0.0 & 12.5 & 0.0 & $\boldsymbol{8}$ \\
'owners' & 60.0 & 40.0 & 0.0 & 0.0 & 0.0 & 1.8 & 0.0 & 7.0 \\
Lower managers, & 11.1 & 33.3 & 11.1 & 0.0 & 33.3 & 11.1 & 0.0 & $\mathbf{9}$ \\
professional and sales & 20.0 & 30.0 & 6.3 & 0.0 & 20.0 & 1.8 & 0.0 & 7.8 \\
Foremen, & 0.0 & 0.0 & 50.0 & 0.0 & 33.3 & 16.7 & 0.0 & $\mathbf{1 2}$ \\
medium-skilled workers & 0.0 & 0.0 & 37.5 & 0.0 & 26.7 & 3.5 & 0.0 & 10.4 \\
Farmers (lavradores) & 0.0 & 40.0 & 20.0 & 20.0 & 20.0 & 0.0 & 0.0 & $\mathbf{5}$ \\
& 0.0 & 20.0 & 6.3 & 100.0 & 6.7 & 0.0 & 0.0 & 4.3
\end{tabular}


Appendix Table 2 (Cont.)

\begin{tabular}{|c|c|c|c|c|c|c|c|c|}
\hline \multirow[t]{2}{*}{ Lower-skilled workers } & 11.1 & 0.0 & 33.3 & 0.0 & 55.6 & 0.0 & 0.0 & 9 \\
\hline & 20.0 & 0.0 & 18.8 & 0.0 & 33.3 & 0.0 & 0.0 & 7.8 \\
\hline Unskilled workers & 0.0 & 1.7 & 8.3 & 0.0 & 3.3 & 81.7 & 5.0 & 60 \\
\hline (includes 'seamen') & 0.0 & 10.0 & 31.3 & 0.0 & 13.3 & 86.0 & 27.3 & 52.2 \\
\hline Lower-skilled, & 0.0 & 0.0 & 0.0 & 0.0 & 0.0 & 33.3 & 66.7 & 12 \\
\hline unskilled farm workers & 0.0 & 0.0 & 0.0 & 0.0 & 0.0 & 7.0 & 72.7 & 10.4 \\
\hline Total & 4.3 & 8.7 & 13.9 & 0.9 & 13.0 & 49.6 & 9.6 & 115 \\
\hline$N$ & 5 & 10 & 16 & 1 & 15 & 57 & 11 & 115 \\
\hline $1880-1882$ & $1+2$ & $3+4+5$ & $6+7$ & 8 & 9 & 11 & $10+12$ & Total N \\
\hline \multicolumn{9}{|l|}{ Higher managers, } \\
\hline $\begin{array}{l}\text { higher professionals, } \\
\text { 'owners' }\end{array}$ & 60.0 & 57.1 & 16.7 & 0.0 & 0.0 & 4.2 & 0.0 & 16.4 \\
\hline \multirow{2}{*}{$\begin{array}{l}\text { Lower managers, } \\
\text { professional and sales }\end{array}$} & 11.1 & 11.1 & 22.2 & 0.0 & 44.4 & 11.1 & 0.0 & 9 \\
\hline & 20.0 & 14.3 & 33.3 & 0.0 & 57.1 & 4.2 & 0.0 & 16.4 \\
\hline \multirow{2}{*}{$\begin{array}{l}\text { Foremen, } \\
\text { medium-skilled workers }\end{array}$} & 0.0 & 0.0 & 66.7 & 0.0 & 0.0 & 33.3 & 0.0 & 3 \\
\hline & 0.0 & 0.0 & 33.3 & 0.0 & 0.0 & 4.2 & 0.0 & 5.5 \\
\hline \multirow[t]{2}{*}{ Farmers (lavradores) } & 33.3 & 33.3 & 0.0 & 33.3 & 0.0 & 0.0 & 0.0 & 3 \\
\hline & 20.0 & 14.3 & 0.0 & 100.0 & 0.0 & 0.0 & 0.0 & 5.5 \\
\hline \multirow[t]{2}{*}{ Lower-skilled workers } & 0.0 & 0.0 & 0.0 & 0.0 & 100.0 & 0.0 & 0.0 & 2 \\
\hline & 0.0 & 0.0 & 0.0 & 0.0 & 28.6 & 0.0 & 0.0 & 3.6 \\
\hline Unskilled workers & 0.0 & 4.3 & 0.0 & 0.0 & 4.3 & 82.6 & 8.7 & 23 \\
\hline (includes 'seamen') & 0.0 & 14.3 & 0.0 & 0.0 & 14.3 & 79.2 & 40.0 & 41.8 \\
\hline Lower-skilled, & 0.0 & 0.0 & 16.7 & 0.0 & 0.0 & 33.3 & 50.0 & 6 \\
\hline unskilled farm workers & 0.0 & 0.0 & 16.7 & 0.0 & 0.0 & 8.3 & 60.0 & 10.9 \\
\hline Total & 9.1 & 12.7 & 10.9 & 1.8 & 12.7 & 43.6 & 9.1 & 55 \\
\hline$N$ & 5 & 7 & 6 & 1 & 7 & 24 & 5 & 55 \\
\hline $1900-1902$ & $1+2$ & $3+4+5$ & $6+7$ & 8 & 9 & 11 & $10+12$ & Total $\mathrm{N}$ \\
\hline
\end{tabular}

$\begin{array}{lrrrrrrrc}\text { Higher managers, } & & & & & & & & \\ \text { higher professionals, } & 57.1 & 14.3 & 0.0 & 14.3 & 0.0 & 14.3 & 0.0 & 7 \\ \text { 'owners' } & 100.0 & 20.0 & 0.0 & 50.0 & 0.0 & 5.3 & 0.0 & 10.9 \\ \text { Lower managers, } & 0.0 & 100.0 & 0.0 & 0.0 & 0.0 & 0.0 & 0.0 & \mathbf{2} \\ \text { professional and sales } & 0.0 & 40.0 & 0.0 & 0.0 & 0.0 & 0.0 & 0.0 & 3.1 \\ \text { Foremen, } & 0.0 & 0.0 & 75.0 & 0.0 & 25.0 & 0.0 & 0.0 & \mathbf{4} \\ \text { medium-skilled workers } & 0.0 & 0.0 & 100.0 & 0.0 & 33.3 & 0.0 & 0.0 & 6.3 \\ \text { Farmers (lavradores) } & 0.0 & 0.0 & 0.0 & 100.0 & 0.0 & 0.0 & 0.0 & \mathbf{1} \\ & 0.0 & 0.0 & 0.0 & 50.0 & 0.0 & 0.0 & 0.0 & 1.6 \\ \text { Lower-skilled workers } & 0.0 & 0.0 & 0.0 & 0.0 & 100.0 & 0.0 & 0.0 & \mathbf{1} \\ & 0.0 & 0.0 & 0.0 & 0.0 & 33.3 & 0.0 & 0.0 & 1.6 \\ \text { Unskilled workers } & 0.0 & 5.1 & 0.0 & 0.0 & 2.6 & 33.3 & 59.0 & \mathbf{3 9} \\ \text { (includes 'seamen') } & 0.0 & 40.0 & 0.0 & 0.0 & 33.3 & 68.4 & 82.1 & 60.9 \\ \text { Lower-skilled, } & 0.0 & 0.0 & 0.0 & 0.0 & 0.0 & 50.0 & 50.0 & \mathbf{1 0} \\ \text { unskilled farm workers } & 0.0 & 0.0 & 0.0 & 0.0 & 0.0 & 26.3 & 17.9 & 15.6 \\ \text { Total } & 6.3 & 7.8 & 4.7 & 3.1 & 4.7 & 29.7 & 43.8 & \mathbf{6 4} \\ N & \mathbf{4} & \mathbf{5} & \mathbf{3} & \mathbf{2} & \mathbf{3} & \mathbf{1 9} & \mathbf{2 8} & \mathbf{6 4}\end{array}$


Appendix Table 2 (Cont.)

\begin{tabular}{lccrrrrrc}
\hline 1911-1913 & $1+2$ & $3+4+5$ & $6+7$ & 8 & 9 & 11 & $10+12$ & Total N \\
\hline Higher managers, & & & & & & & & \\
higher professionals, & 37.0 & 14.8 & 3.7 & 11.1 & 7.4 & 11.1 & 14.8 & $\mathbf{2 7}$ \\
'owners' & 47.6 & 11.8 & 3.1 & 25.0 & 5.7 & 2.3 & 10.5 & 8.9 \\
Lower managers, & 14.3 & 34.3 & 14.3 & 0.0 & 22.9 & 11.4 & 2.9 & $\mathbf{3 5}$ \\
professional and sales & 23.8 & 35.3 & 15.6 & 0.0 & 22.9 & 3.1 & 2.6 & 11.6 \\
Foremen, & 0.0 & 20.7 & 51.7 & 3.4 & 10.3 & 13.8 & 0.0 & $\mathbf{2 9}$ \\
medium-skilled workers & 0.0 & 17.6 & 46.9 & 8.3 & 8.6 & 3.1 & 0.0 & 9.6 \\
Farmers (lavradores) & 13.0 & 4.3 & 4.3 & 30.4 & 17.4 & 21.7 & 8.7 & $\mathbf{2 3}$ \\
& 14.3 & 2.9 & 3.1 & 58.3 & 11.4 & 3.8 & 5.3 & 7.6 \\
Lower-skilled workers & 5.9 & 23.5 & 17.6 & 0.0 & 41.2 & 11.8 & 0.0 & $\mathbf{1 7}$ \\
& 4.8 & 11.8 & 9.4 & 0.0 & 20.0 & 1.5 & 0.0 & 5.6 \\
Unskilled workers & 1.5 & 4.5 & 4.5 & 0.8 & 5.3 & 72.0 & 11.4 & $\mathbf{1 3 2}$ \\
(includes 'seamen') & 9.5 & 17.6 & 18.8 & 8.3 & 20.0 & 72.5 & 39.5 & 43.6 \\
Lower-skilled, & 0.0 & 2.5 & 2.5 & 0.0 & 10.0 & 45.0 & 40.0 & $\mathbf{4 0}$ \\
unskilled farm workers & 0.0 & 2.9 & 3.1 & 0.0 & 11.4 & 13.7 & 42.1 & 13.2 \\
Total & 6.9 & 11.2 & 10.6 & 4.0 & 11.6 & 43.2 & 12.5 & $\mathbf{3 0 3}$ \\
$N$ & $\mathbf{2 1}$ & $\mathbf{3 4}$ & $\mathbf{3 2}$ & $\mathbf{1 2}$ & $\mathbf{3 5}$ & $\mathbf{1 3 1}$ & $\mathbf{3 8}$ & $\mathbf{3 0 3}$ \\
& & & & & & & & \\
1925-1927 & $1+2$ & $3+4+5$ & $6+7$ & 8 & 9 & 11 & $10+12$ & Total $\mathrm{N}$ \\
\hline
\end{tabular}

\begin{tabular}{lrrrrrrrc} 
Higher managers, & & & & & & & & \\
higher professionals, & 21.9 & 40.6 & 3.1 & 6.3 & 12.5 & 15.6 & 0.0 & $\mathbf{3 2}$ \\
'owners' & 53.8 & 29.5 & 2.1 & 13.3 & 9.8 & 4.1 & 0.0 & 9.6 \\
Lower managers, & 2.2 & 42.2 & 17.8 & 2.2 & 15.6 & 13.3 & 6.7 & $\mathbf{4 5}$ \\
professional and sales & 7.7 & 43.2 & 16.7 & 6.7 & 17.1 & 4.9 & 6.3 & 13.6 \\
Foremen, & 5.1 & 25.6 & 51.3 & 0.0 & 10.3 & 5.1 & 2.6 & $\mathbf{3 9}$ \\
medium-skilled workers & 15.4 & 22.7 & 41.7 & 0.0 & 9.8 & 1.6 & 2.1 & 11.7 \\
Farmers (lavradores) & 7.4 & 0.0 & 0.0 & 40.7 & 55.0 & 20.0 & 0.0 & $\mathbf{2 0}$ \\
& 15.4 & 0.0 & 0.0 & 73.3 & 26.8 & 3.3 & 0.0 & 6.0 \\
Lower-skilled workers & 5.0 & 0.0 & 15.0 & 5.0 & 7.4 & 63.9 & 14.8 & $\mathbf{1 0 8}$ \\
& 7.7 & 0.0 & 6.3 & 6.7 & & & & \\
Unskilled workers & 0.0 & 1.9 & 12.0 & 0.0 & & & & \\
(includes 'seamen') & 0.0 & 4.5 & 27.1 & 0.0 & 19.5 & 56.1 & 33.3 & 32.5 \\
Lower-skilled, & 0.0 & 0.0 & 4.9 & 0.0 & 8.2 & 49.2 & 37.7 & $\mathbf{6 1}$ \\
unskilled farm workers & 0.0 & 0.0 & 6.3 & 0.0 & 12.2 & 24.4 & 47.9 & 18.4 \\
Total & 3.9 & 13.3 & 14.5 & 4.5 & 12.3 & 37.0 & 14.5 & $\mathbf{3 3 2}$ \\
$N$ & $\mathbf{1 3}$ & $\mathbf{4 4}$ & $\mathbf{4 8}$ & $\mathbf{1 5}$ & $\mathbf{4 1}$ & $\mathbf{1 2 3}$ & $\mathbf{4 8}$ & $\mathbf{3 3 2}$ \\
& & & & & & & & \\
1935-1937 & $1+2$ & $3+4+5$ & $6+7$ & 8 & 9 & 11 & $10+12$ & Total $\mathbf{N}$ \\
\hline Higher managers, & & & & & & & & \\
higher professionals, & 4.9 & 39.0 & 7.3 & 14.6 & 7.3 & 26.8 & 0.0 & $\mathbf{4 1}$ \\
'owners' & 33.3 & 25.8 & 5.8 & 37.5 & 7.5 & 5.6 & 0.0 & 10.6 \\
Lower managers, & 2.9 & 47.1 & 14.7 & 0.0 & 20.6 & 14.7 & 0.0 & $\mathbf{3 4}$ \\
professional and sales & 16.7 & 25.8 & 9.6 & 0.0 & 17.5 & 2.6 & 0.0 & 8.8 \\
Foremen, & 0.0 & 20.0 & 44.4 & 0.0 & 26.7 & 8.9 & 0.0 & $\mathbf{4 5}$ \\
& & & & & & & &
\end{tabular}


Appendix Table 2 (Cont.)

\begin{tabular}{|c|c|c|c|c|c|c|c|c|}
\hline medium-skilled workers & 0.0 & 14.5 & 38.5 & 0.0 & 30.0 & 2.0 & 0.0 & 11.7 \\
\hline \multirow[t]{2}{*}{ Farmers (lavradores) } & 7.9 & 7.9 & 2.6 & 26.3 & 10.5 & 39.5 & 5.3 & 38 \\
\hline & 50.0 & 4.8 & 1.9 & 62.5 & 10.0 & 7.7 & 14.3 & 9.8 \\
\hline \multirow[t]{2}{*}{ Lower-skilled workers } & 0.0 & 30.4 & 39.1 & 0.0 & 17.4 & 13.0 & 0.0 & 23 \\
\hline & 0.0 & 11.3 & 17.3 & 0.0 & 10.0 & 1.5 & 0.0 & 6.0 \\
\hline Unskilled workers & 0.0 & 6.3 & 8.0 & 0.0 & 5.2 & 79.9 & 0.6 & 174 \\
\hline (includes 'seamen') & 0.0 & 17.7 & 26.9 & 0.0 & 22.5 & 70.9 & 7.1 & 45.1 \\
\hline Lower-skilled, & 0.0 & 0.0 & 0.0 & 0.0 & 3.2 & 61.3 & 35.5 & 31 \\
\hline unskilled farm workers & 0.0 & 0.0 & 0.0 & 0.0 & 2.5 & 9.7 & 78.6 & 8.0 \\
\hline Total & 1.6 & 16.1 & 13.5 & 4.1 & 10.4 & 50.8 & 3.6 & 386 \\
\hline$N$ & 6 & 62 & 52 & 16 & 40 & 196 & 14 & 386 \\
\hline $1955-1957$ & $1+2$ & $3+4+5$ & $6+7$ & 8 & 9 & 11 & $10+12$ & Total $\mathrm{N}$ \\
\hline \multicolumn{9}{|l|}{ Higher managers, } \\
\hline $\begin{array}{l}\text { higher professionals, } \\
\text { 'owners' }\end{array}$ & 35.3 & $\begin{array}{r}53.5 \\
7.4\end{array}$ & 4.0 & 12.5 & $\begin{array}{l}3.1 \\
1.2\end{array}$ & $\begin{array}{r}18.5 \\
2.2\end{array}$ & $\begin{array}{l}. .4 \\
6.7\end{array}$ & 4.8 \\
\hline \multirow{2}{*}{$\begin{array}{l}\text { Lower managers, } \\
\text { professional and sales }\end{array}$} & 11.8 & 60.5 & 11.8 & 1.3 & 11.8 & 2.6 & 0.0 & 76 \\
\hline & 52.9 & 38.0 & 12.0 & 12.5 & 11.0 & 0.9 & 0.0 & 13.6 \\
\hline Foremen, & 0.0 & 26.6 & 40.6 & 0.0 & 20.3 & 12.5 & 0.0 & 64 \\
\hline medium-skilled workers & 0.0 & 14.0 & 34.7 & 0.0 & 15.9 & 3.5 & 0.0 & 11.4 \\
\hline \multirow[t]{2}{*}{ Farmers (lavradores) } & 5.6 & 22.2 & 0.0 & 27.8 & 11.1 & 22.2 & 11.1 & 18 \\
\hline & 5.9 & 3.3 & 0.0 & 62.5 & 2.4 & 1.8 & 6.7 & 3.2 \\
\hline \multirow[t]{2}{*}{ Lower-skilled workers } & 2.0 & 39.2 & 11.8 & 0.0 & 39.2 & 7.8 & 0.0 & 51 \\
\hline & 5.9 & 16.5 & 8.0 & 0.0 & 24.4 & 1.8 & 0.0 & 9.1 \\
\hline Unskilled workers & 0.0 & 7.7 & 10.1 & 0.3 & 11.7 & 65.8 & 4.4 & 298 \\
\hline (includes 'seamen') & 0.0 & 19.0 & 40.0 & 12.5 & 42.7 & 86.7 & 43.3 & 53.3 \\
\hline \multicolumn{9}{|l|}{ Lower-skilled, unskilled } \\
\hline (includes ‘fishermen') & 0.0 & 1.7 & 1.3 & 0.0 & 2.4 & 3.1 & 43.3 & 4.5 \\
\hline Total & 3.0 & 21.6 & 13.4 & 1.4 & 14.7 & 40.4 & 5.4 & 559 \\
\hline$N$ & 17 & 121 & 75 & 8 & 82 & 226 & 30 & 559 \\
\hline
\end{tabular}

Note: HISCLASS codes; $1+2=$ Higher managers, higher professionals and 'owners'; $3+4+5=$ Lower managers, professional and sales; $6+7=$ Foremen, medium-skilled workers; $8=$ Farmers (lavradores); $9=$ Lower-skilled workers; $11=$ Unskilled workers (includes 'seamen'): $10+12=$ Lower skilled, unskilled farm workers (includes 'fishermen'); Total (relative values for row and column) $=100$ per cent; $N=$ Number of cases observed. Source: Historical Sample of Portuguese Social Mobility (HSPSM). 
Appendix TABLe 3

Intergenerational mobility in Setúbal, 1900-1957: a comparison of the social classes of fathers and sons at first marriage (relative and absolute values)

\begin{tabular}{|c|c|c|c|c|c|c|c|c|}
\hline \multirow{2}{*}{$\begin{array}{l}\text { Social class } \\
\text { of the father } \\
1900-1902\end{array}$} & \multicolumn{8}{|c|}{ Social class of the son } \\
\hline & $1+2$ & $3+4+5$ & $6+7$ & 8 & 9 & 11 & $10+12$ & Total $\mathrm{N}$ \\
\hline \multirow{2}{*}{$\begin{array}{l}\text { Higher managers, } \\
\text { higher professionals, } \\
\text { 'owners' }\end{array}$} & 0.0 & 0.0 & 0.0 & 0.0 & 0.0 & 0.0 & 0.0 & 0 \\
\hline & 0.0 & 0.0 & 0.0 & 0.0 & 0.0 & 0.0 & 0.0 & 0.0 \\
\hline \multirow{6}{*}{$\begin{array}{l}\text { Lower managers, } \\
\text { professional and sales } \\
\text { Foremen, } \\
\text { medium-skilled workers } \\
\text { Farmers (lavradores) }\end{array}$} & 0.0 & 100.0 & 0.0 & 0.0 & 0.0 & 0.0 & 0.0 & 1 \\
\hline & 0.0 & 16.7 & 0.0 & 0.0 & 0.0 & 0.0 & 0.0 & 1.1 \\
\hline & 0.0 & 0.0 & 0.0 & 0.0 & 0.0 & 0.0 & 0.0 & 0 \\
\hline & 0.0 & 0.0 & 0.0 & 0.0 & 0.0 & 0.0 & 0.0 & 0.0 \\
\hline & 0.0 & 0.0 & 0.0 & 0.0 & 0.0 & 0.0 & 100.0 & 1 \\
\hline & 0.0 & 0.0 & 0.0 & 0.0 & 0.0 & 0.0 & 3.4 & 1.1 \\
\hline \multirow[t]{2}{*}{ Lower-skilled workers } & 0.0 & 33.3 & 0.0 & 0.0 & 0.0 & 33.3 & 33.3 & 3 \\
\hline & 0.0 & 16.7 & 0.0 & 0.0 & 0.0 & 3.2 & 3.4 & 3.4 \\
\hline \multirow{6}{*}{$\begin{array}{l}\text { Unskilled workers } \\
\text { (includes 'seamen') } \\
\text { Lower-skilled, } \\
\text { unskilled farm workers } \\
\text { Total } \\
N\end{array}$} & 0.0 & 7.7 & 3.8 & 0.0 & 28.8 & 38.5 & 21.2 & 52 \\
\hline & 0.0 & 66.7 & 40.0 & 0.0 & 93.8 & 64.5 & 37.9 & 59.8 \\
\hline & 0.0 & 0.0 & 10.0 & 0.0 & 3.3 & 33.3 & 53.3 & 30 \\
\hline & 0.0 & 0.0 & 60.0 & 0.0 & 6.3 & 32.3 & 55.2 & 34.5 \\
\hline & 4.3 & 8.7 & 13.9 & 0.9 & 13.0 & 49.6 & 9.6 & 87 \\
\hline & 0 & 6 & 5 & 0 & 16 & 31 & 29 & 87 \\
\hline $1911-1913$ & $1+2$ & $3+4+5$ & $6+7$ & 8 & 9 & 11 & $10+12$ & Total $\mathrm{N}$ \\
\hline \multirow{3}{*}{$\begin{array}{l}\text { Higher managers, } \\
\text { higher professionals, } \\
\text { 'owners' }\end{array}$} & & & & & & & & \\
\hline & 28.6 & 42.9 & 0.0 & 0.0 & 10.7 & 14.3 & 3.6 & 28 \\
\hline & 72.7 & 29.3 & 0.0 & 0.0 & 6.1 & 3.2 & 7.7 & 10.7 \\
\hline \multirow{2}{*}{$\begin{array}{l}\text { Lower managers, } \\
\text { professional and sales }\end{array}$} & 10.5 & 57.9 & 10.5 & 0.0 & 10.5 & 10.5 & 0.0 & 19 \\
\hline & 18.2 & 26.8 & 9.5 & 0.0 & 4.1 & 1.6 & 0.0 & 7.3 \\
\hline \multirow{2}{*}{$\begin{array}{l}\text { Foremen, } \\
\text { medium-skilled workers }\end{array}$} & 0.0 & 24.0 & 36.0 & 0.0 & 24.0 & 16.0 & 0.0 & 25 \\
\hline & 0.0 & 14.6 & 42.9 & 0.0 & 12.2 & 3.2 & 0.0 & 9.6 \\
\hline \multirow[t]{2}{*}{ Farmers (lavradores) } & 0.0 & 37.5 & 0.0 & 0.0 & 12.5 & 50.0 & 0.0 & 8 \\
\hline & 0.0 & 7.3 & 0.0 & 0.0 & 2.0 & 3.2 & 0.0 & 3.1 \\
\hline \multirow[t]{2}{*}{ Lower-skilled workers } & 3.8 & 11.5 & 3.8 & 0.0 & 69.2 & 7.7 & 3.8 & 26 \\
\hline & 9.1 & 7.3 & 4.8 & 0.0 & 36.7 & 1.6 & 7.7 & 10.0 \\
\hline \multirow{6}{*}{$\begin{array}{l}\text { Unskilled workers } \\
\text { (includes 'seamen') } \\
\text { Lower-skilled, } \\
\text { unskilled farm workers } \\
\text { Total } \\
N\end{array}$} & 0.0 & 3.3 & 5.0 & 0.0 & 13.3 & 75.0 & 3.3 & 120 \\
\hline & 0.0 & 9.8 & 28.6 & 0.0 & 32.7 & 71.4 & 30.8 & 46.0 \\
\hline & 0.0 & 5.7 & 8.6 & 0.0 & 8.6 & 57.1 & 20.0 & 35 \\
\hline & 0.0 & 4.9 & 14.3 & 0.0 & 6.1 & 15.9 & 53.8 & 13.4 \\
\hline & 4.2 & 15.7 & 8.0 & 0.0 & 18.8 & 48.3 & 5.0 & 261 \\
\hline & 11 & 41 & 21 & 0 & 49 & 126 & 13 & 261 \\
\hline
\end{tabular}


Appendix Table 3 (Cont.)

\begin{tabular}{lrrrrrrrc}
\hline $1925-1927$ & $1+2$ & $3+4+5$ & $6+7$ & 8 & 9 & 11 & $10+12$ & Total $\mathrm{N}$ \\
\hline Higher managers, & & & & & & & & \\
higher professionals, & 12.5 & 54.2 & 4.2 & 0.0 & 20.8 & 8.3 & 0.0 & $\mathbf{2 4}$ \\
'owners' & 60.0 & 21.0 & 4.3 & 0.0 & 9.8 & 1.7 & 0.0 & 9.3 \\
Lower managers, & 3.4 & 65.5 & 3.4 & 0.0 & 20.7 & 6.9 & 0.0 & $\mathbf{2 9}$ \\
professional and sales & 20.0 & 30.6 & 4.3 & 0.0 & 11.8 & 1.7 & 0.0 & 11.2 \\
Foremen, & 0.0 & 11.1 & 44.4 & 0.0 & 27.8 & 16.7 & 0.0 & $\mathbf{1 8}$ \\
medium-skilled workers & 0.0 & 3.2 & 34.8 & 0.0 & 9.8 & 2.6 & 0.0 & 7.0 \\
Farmers (lavradores) & 0.0 & 25.0 & 12.5 & 12.5 & 37.5 & 12.5 & 0.0 & $\boldsymbol{8}$ \\
& 0.0 & 3.2 & 4.3 & 100.0 & 5.9 & 0.9 & 0.0 & 3.1 \\
Lower-skilled workers & 0.0 & 30.8 & 7.7 & 0.0 & 46.2 & 15.4 & 0.0 & $\mathbf{3 9}$ \\
& 0.0 & 19.4 & 13.0 & 0.0 & 35.3 & 5.2 & 0.0 & 15.1 \\
Unskilled workers & 0.0 & 9.5 & 5.6 & 0.0 & 10.3 & 74.6 & 0.0 & $\mathbf{1 2 6}$ \\
(includes 'seamen') & 0.0 & 19.4 & 30.4 & 0.0 & 25.5 & 81.7 & 0.0 & 48.8 \\
Lower-skilled, & 7.1 & 14.3 & 14.3 & 0.0 & 7.1 & 50.0 & 7.1 & $\mathbf{1 4}$ \\
unskilled farm workers & 20.0 & 3.2 & 8.7 & 0.0 & 2.0 & 6.1 & 100.0 & 5.4 \\
Total & 1.9 & 24.0 & 8.9 & 0.4 & 19.8 & 44.6 & 0.4 & $\mathbf{2 5 8}$ \\
$N$ & $\mathbf{5}$ & $\mathbf{6 2}$ & $\mathbf{2 3}$ & $\mathbf{1}$ & $\mathbf{5 1}$ & $\mathbf{1 1 5}$ & $\mathbf{1}$ & $\mathbf{2 5 8}$
\end{tabular}

Higher managers,

\begin{tabular}{lrrrrrrrc} 
higher professionals, & 14.8 & 37.0 & 7.4 & 3.7 & 22.2 & 14.8 & 0.0 & $\mathbf{2 7}$ \\
'owners' & 66.7 & 13.5 & 3.2 & 25.0 & 10.5 & 2.1 & 0.0 & 6.8 \\
Lower managers, & 0.0 & 57.9 & 24.6 & 0.0 & 15.8 & 1.8 & 0.0 & $\mathbf{5 7}$ \\
professional and sales & 0.0 & 44.6 & 22.2 & 0.0 & 15.8 & 0.5 & 0.0 & 14.4 \\
Foremen, & 2.7 & 16.2 & 45.9 & 0.0 & 16.2 & 18.9 & 0.0 & $\mathbf{3 7}$ \\
medium-skilled workers & 16.7 & 8.1 & 27.0 & 0.0 & 10.5 & 3.7 & 0.0 & 9.4 \\
Farmers (lavradores) & 0.0 & 25.0 & 0.0 & 75.0 & 0.0 & 0.0 & 0.0 & 4 \\
& 0.0 & 1.4 & 0.0 & 75.0 & 0.0 & 0.0 & 0.0 & 1.0 \\
Lower-skilled workers & 2.2 & 10.9 & 26.1 & 0.0 & 37.0 & 23.9 & 0.0 & $\mathbf{4 6}$ \\
& 16.7 & 6.8 & 19.0 & 0.0 & 29.8 & 5.8 & 0.0 & 11.6 \\
Unskilled workers & 0.0 & 7.7 & 8.1 & 0.0 & 8.6 & 75.2 & 0.5 & $\mathbf{2 2 2}$ \\
(includes 'seamen') & 0.0 & 23.0 & 28.6 & 0.0 & 33.3 & 87.9 & 100.0 & 56.2 \\
Lower-skilled, & 0.0 & 100.0 & 0.0 & 0.0 & 0.0 & 0.0 & 0.0 & 2 \\
unskilled farm workers & 0.0 & 2.7 & 0.0 & 0.0 & 0.0 & 0.0 & 0.0 & 0.5 \\
Total & 1.5 & 18.7 & 15.9 & 1.0 & 14.4 & 48.1 & 0.3 & $\mathbf{3 9 5}$ \\
$N$ & $\mathbf{6}$ & 74 & $\mathbf{6 3}$ & $\mathbf{4}$ & $\mathbf{5 7}$ & $\mathbf{1 9 0}$ & $\mathbf{1}$ & $\mathbf{3 9 5}$ \\
& & & & & & & & \\
1955-1957 & $1+2$ & $3+4+5$ & $6+7$ & 8 & 9 & 11 & $10+12$ & Total $\mathrm{N}$ \\
\hline Higher managers, & & & & & & & & \\
higher professionals, & 18.2 & 45.5 & 18.2 & 0.0 & 9.1 & 9.1 & 0.0 & $\mathbf{1 1}$ \\
'owners' & 40.0 & 14.7 & 6.3 & 0.0 & 1.7 & 1.0 & 0.0 & 4.3 \\
Lower managers, & 7.7 & 42.3 & 15.4 & 0.0 & 26.9 & 7.7 & 0.0 & $\mathbf{2 6}$ \\
professional and sales & 40.0 & 32.4 & 12.5 & 0.0 & 11.7 & 2.0 & 0.0 & 10.3
\end{tabular}


Appendix Table 3 (Cont.)

\begin{tabular}{lrrrrrrrc}
\hline Foremen, & 3.8 & 7.7 & 34.6 & 0.0 & 46.2 & 7.7 & 0.0 & \multicolumn{2}{c}{6} \\
medium-skilled workers & 20.0 & 5.9 & 28.1 & 0.0 & 20.0 & 2.0 & 0.0 & 10.3 \\
Farmers (lavradores) & 0.0 & 16.7 & 0.0 & 33.3 & 16.7 & 16.7 & 16.7 & $\mathbf{6}$ \\
& 0.0 & 2.9 & 0.0 & 100.0 & 1.7 & 1.0 & 4.8 & 2.4 \\
Lower-skilled workers & 0.0 & 17.1 & 5.7 & 0.0 & 45.7 & 31.4 & 0.0 & $\mathbf{3 5}$ \\
& 0.0 & 17.6 & 6.3 & 0.0 & 26.7 & 11.1 & 0.0 & 13.8 \\
Unskilled workers & 0.0 & 6.2 & 11.5 & 0.0 & 16.2 & 57.7 & 8.5 & $\mathbf{1 3 0}$ \\
(includes 'seamen') & 0.0 & 23.5 & 46.9 & 0.0 & 35.0 & 75.8 & 52.4 & 51.4 \\
Lower-skilled, & 0.0 & 5.3 & 0.0 & 0.0 & 10.5 & 36.8 & 47.4 & $\mathbf{1 9}$ \\
unskilled farm workers & 0.0 & 2.9 & 0.0 & 0.0 & 3.3 & 7.1 & 42.9 & 7.5 \\
Total & 2.0 & 13.4 & 12.6 & 0.8 & 23.7 & 39.1 & 8.3 & $\mathbf{2 5 3}$ \\
$N$ & $\mathbf{5}$ & $\mathbf{3 4}$ & $\mathbf{3 2}$ & $\mathbf{2}$ & $\mathbf{6 0}$ & $\mathbf{9 9}$ & $\mathbf{2 1}$ & $\mathbf{2 5 3}$ \\
\hline \hline
\end{tabular}

Notes and sources: See Appendix Table 2.

\section{A PPENDIX TABLE 4}

Intergenerational mobility in Barreiro, 1911-1957: a comparison of the social classes of fathers and sons at first marriage (relative and absolute values)

\begin{tabular}{|c|c|c|c|c|c|c|c|c|}
\hline \multirow{2}{*}{$\begin{array}{l}\text { Social class of } \\
\text { the father } \\
1911-1913\end{array}$} & \multicolumn{8}{|c|}{ Social class of the son } \\
\hline & $1+2$ & $3+4+5$ & $6+7$ & 8 & 9 & 11 & $10+12$ & Total $\mathrm{N}$ \\
\hline \multirow{2}{*}{$\begin{array}{l}\text { Higher managers, } \\
\text { higher professionals, } \\
\text { 'owners' }\end{array}$} & & & & & & & & \\
\hline & $\begin{array}{r}5.6 \\
100.0\end{array}$ & $\begin{array}{l}27.8 \\
17.2\end{array}$ & $\begin{array}{l}5.6 \\
4.8\end{array}$ & $\begin{array}{l}0.0 \\
0.0\end{array}$ & $\begin{array}{l}38.9 \\
19.4\end{array}$ & $\begin{array}{r}22.2 \\
8.7\end{array}$ & $\begin{array}{l}0.0 \\
0.0\end{array}$ & $\begin{array}{l}18 \\
13.5\end{array}$ \\
\hline \multirow{4}{*}{$\begin{array}{l}\text { Lower managers, } \\
\text { professional and sales } \\
\text { Foremen, } \\
\text { medium-skilled workers }\end{array}$} & 0.0 & 46.7 & 20.0 & 0.0 & 33.3 & 0.0 & 0.0 & 15 \\
\hline & 0.0 & 24.1 & 14.3 & 0.0 & 13.9 & 0.0 & 0.0 & 11.3 \\
\hline & 0.0 & 25.0 & 35.0 & 0.0 & 15.0 & 25.0 & 0.0 & 20 \\
\hline & 0.0 & 17.2 & 33.3 & 0.0 & 8.3 & 10.9 & 0.0 & 15.0 \\
\hline \multirow[t]{2}{*}{ Farmers (lavradores) } & 0.0 & 0.0 & 0.0 & 0.0 & 50.0 & 50.0 & 0.0 & 4 \\
\hline & 0.0 & 0.0 & 0.0 & 0.0 & 5.6 & 4.3 & 0.0 & 3.0 \\
\hline \multirow[t]{2}{*}{ Lower-skilled workers } & 0.0 & 17.6 & 11.8 & 0.0 & 52.9 & 17.6 & 0.0 & 17 \\
\hline & 0.0 & 10.3 & 9.5 & 0.0 & 25.0 & 6.5 & 0.0 & 12.8 \\
\hline Unskilled workers & 0.0 & 15.8 & 14.0 & 0.0 & 15.8 & 54.4 & 0.0 & 57 \\
\hline (includes 'seamen') & 0.0 & 31.0 & 38.1 & 0.0 & 25.0 & 67.4 & 0.0 & 42.9 \\
\hline Lower-skilled, & 0.0 & 0.0 & 0.0 & 0.0 & 50.0 & 50.0 & 0.0 & 2 \\
\hline unskilled farm workers & 0.0 & 0.0 & 0.0 & 0.0 & 2.8 & 2.2 & 0.0 & 1.5 \\
\hline Total & 0.8 & 21.8 & 15.8 & 0.0 & 27.1 & 34.6 & 0.0 & 133 \\
\hline$N$ & 1 & 29 & 21 & 0 & 36 & 46 & 0 & 133 \\
\hline $1925-1927$ & $1+2$ & $3+4+5$ & $6+7$ & 8 & 9 & 11 & $10+12$ & Total $\mathrm{N}$ \\
\hline $\begin{array}{l}\text { Higher managers, } \\
\text { higher professionals, } \\
\text { 'owners' }\end{array}$ & $\begin{array}{l}0.0 \\
0.0\end{array}$ & $\begin{array}{l}33.3 \\
15.4\end{array}$ & $\begin{array}{r}11.1 \\
5.7\end{array}$ & $\begin{array}{l}0.0 \\
0.0\end{array}$ & $\begin{array}{r}11.1 \\
5.9\end{array}$ & $\begin{array}{r}44.4 \\
9.1\end{array}$ & $\begin{array}{l}0.0 \\
0.0\end{array}$ & 18 \\
\hline
\end{tabular}


Appendix Table 4 (Cont.)

\begin{tabular}{|c|c|c|c|c|c|c|c|c|}
\hline Lower managers, & 0.0 & 46.4 & 14.3 & 0.0 & 14.3 & 25.0 & 0.0 & 28 \\
\hline professional and sales & 0.0 & 33.3 & 11.4 & 0.0 & 11.8 & 8.0 & 0.0 & 14.2 \\
\hline Foremen, & 0.0 & 13.0 & 39.1 & 0.0 & 30.4 & 17.4 & 0.0 & 23 \\
\hline medium-skilled workers & 0.0 & 7.7 & 25.7 & 0.0 & 20.6 & 4.5 & 0.0 & 11.7 \\
\hline \multirow[t]{2}{*}{ Farmers (lavradores) } & 0.0 & 25.0 & 0.0 & 0.0 & 25.0 & 50.0 & 0.0 & 4 \\
\hline & 0.0 & 2.6 & 0.0 & 0.0 & 2.9 & 2.3 & 0.0 & 2.0 \\
\hline \multirow[t]{2}{*}{ Lower-skilled workers } & 0.0 & 14.3 & 42.9 & 0.0 & 35.7 & 7.1 & 0.0 & 14 \\
\hline & 0.0 & 5.1 & 17.1 & 0.0 & 14.7 & 1.1 & 0.0 & 7.1 \\
\hline Unskilled workers & 0.0 & 12.9 & 11.8 & 0.0 & 12.9 & 62.4 & 0.0 & 93.0 \\
\hline (includes 'seamen') & 0.0 & 30.8 & 31.4 & 0.0 & 35.3 & 65.9 & 0.0 & 47.2 \\
\hline Lower-skilled, & 0.0 & 11.8 & 17.6 & 0.0 & 17.6 & 47.1 & 5.9 & 17 \\
\hline unskilled farm workers & 0.0 & 5.1 & 8.6 & 0.0 & 8.8 & 9.1 & 100.0 & 8.6 \\
\hline Total & 0.0 & 19.8 & 17.8 & 0.0 & 17.3 & 44.7 & 0.5 & 197 \\
\hline$N$ & 0 & 39 & 35 & 0 & 34 & 88 & 1 & 197 \\
\hline $1935-1937$ & $1+2$ & $3+4+5$ & $6+7$ & 8 & 9 & 11 & $10+12$ & Total $\mathrm{N}$ \\
\hline \multicolumn{9}{|l|}{ Higher managers, } \\
\hline $\begin{array}{l}\text { higher professionals, } \\
\text { 'owners' }\end{array}$ & 0.0 & 16.7 & 3.4 & 0.0 & 6.3 & 2.4 & 0.0 & 5.4 \\
\hline \multirow{2}{*}{$\begin{array}{l}\text { Lower managers, } \\
\text { professional and sales }\end{array}$} & 2.9 & 41.2 & 23.5 & 0.0 & 20.6 & 11.8 & 0.0 & 34 \\
\hline & 100.0 & 46.7 & 13.6 & 0.0 & 11.1 & 4.8 & 0.0 & 14.2 \\
\hline \multirow{4}{*}{$\begin{array}{l}\text { Foremen, } \\
\text { medium-skilled workers } \\
\text { Farmers (lavradores) }\end{array}$} & 0.0 & 4.9 & 46.3 & 0.0 & 29.3 & 19.5 & 0.0 & 41 \\
\hline & 0.0 & 6.7 & 32.2 & 0.0 & 19.0 & 9.5 & 0.0 & 17.1 \\
\hline & 0.0 & 0.0 & 33.3 & 16.7 & 50.0 & 0.0 & 0.0 & 6 \\
\hline & 0.0 & 0.0 & 3.4 & 50.0 & 4.8 & 0.0 & 0.0 & 2.5 \\
\hline \multirow[t]{2}{*}{ Lower-skilled workers } & 0.0 & 9.5 & 28.6 & 0.0 & 38.1 & 23.8 & 0.0 & 21 \\
\hline & 0.0 & 6.7 & 10.2 & 0.0 & 12.7 & 6.0 & 0.0 & 8.8 \\
\hline \multirow{6}{*}{$\begin{array}{l}\text { Unskilled workers } \\
\text { (includes 'seamen') } \\
\text { Lower-skilled, } \\
\text { unskilled farm workers } \\
\text { Total } \\
N\end{array}$} & 0.0 & 5.3 & 19.3 & 0.9 & 21.1 & 52.6 & 0.9 & 114 \\
\hline & 0.0 & 20.0 & 37.3 & 50.0 & 38.1 & 71.4 & 100.0 & 47.5 \\
\hline & 0.0 & 9.1 & 0.0 & 0.0 & 45.5 & 45.5 & 0.0 & 11 \\
\hline & 0.0 & 3.3 & 0.0 & 0.0 & 7.9 & 6.0 & 0.0 & 4.6 \\
\hline & 0.4 & 12.5 & 24.6 & 0.8 & 26.3 & 35.0 & 0.4 & 240 \\
\hline & 1 & 30 & 59 & 2 & 63 & 84 & 1 & 240 \\
\hline $1955-1957$ & $1+2$ & $3+4+5$ & $6+7$ & 8 & 9 & 11 & $10+12$ & Total $\mathrm{N}$ \\
\hline \multirow{2}{*}{$\begin{array}{l}\text { Higher managers, } \\
\text { higher professionals, } \\
\text { 'owners' }\end{array}$} & & & & & & & & \\
\hline & $\begin{array}{l}10.0 \\
50.0\end{array}$ & $\begin{array}{r}50.0 \\
8.8\end{array}$ & $\begin{array}{r}10.0 \\
1.6\end{array}$ & $\begin{array}{l}0.0 \\
0.0\end{array}$ & $\begin{array}{r}10.0 \\
1.1\end{array}$ & $\begin{array}{r}10.0 \\
1.0\end{array}$ & $\begin{array}{l}10.0 \\
16.7\end{array}$ & $\begin{array}{l}10 \\
3.1\end{array}$ \\
\hline \multirow{2}{*}{$\begin{array}{l}\text { Lower managers, } \\
\text { professional and sales }\end{array}$} & 1.3 & 27.8 & 27.8 & 0.0 & 27.8 & 15.2 & 0.0 & 79 \\
\hline & 50.0 & 38.6 & 35.5 & 0.0 & 23.7 & 11.5 & 0.0 & 24.2 \\
\hline \multirow{2}{*}{$\begin{array}{l}\text { Foremen, } \\
\text { medium-skilled workers }\end{array}$} & 0.0 & 14.8 & 31.5 & 0.0 & 31.5 & 22.2 & 0.0 & 54 \\
\hline & 0.0 & 14.0 & 27.4 & 0.0 & 18.3 & 11.5 & 0.0 & 16.5 \\
\hline \multirow[t]{2}{*}{ Farmers (lavradores) } & 0.0 & 7.7 & 15.4 & 23.1 & 46.2 & 7.7 & 0.0 & 13 \\
\hline & 0.0 & 1.8 & 3.2 & 100.0 & 6.5 & 1.0 & 0.0 & 4.0 \\
\hline \multirow[t]{2}{*}{ Lower-skilled workers } & 0.0 & 5.1 & 17.9 & 0.0 & 43.6 & 33.3 & 0.0 & 39 \\
\hline & 0.0 & 3.5 & 11.3 & 0.0 & 18.3 & 12.5 & 0.0 & 11.9 \\
\hline
\end{tabular}


Appendix Table 4 (Cont.)

\begin{tabular}{llrrrrrrc}
\hline Unskilled workers & 0.0 & 13.7 & 10.5 & 0.0 & 23.4 & 48.4 & 4.0 & $\mathbf{1 2 4}$ \\
(includes 'seamen') & 0.0 & 29.8 & 21.0 & 0.0 & 31.2 & 57.7 & 83.3 & 37.9 \\
Lower-skilled, & 0.0 & 25.0 & 0.0 & 0.0 & 12.5 & 62.5 & 0.0 & $\mathbf{8}$ \\
unskilled farm workers & 0.0 & 3.5 & 0.0 & 0.0 & 1.1 & 4.8 & 0.0 & 2.4 \\
Total & 0.6 & 17.4 & 19.0 & 0.9 & 28.4 & 31.8 & 1.8 & $\mathbf{3 2 7}$ \\
$N$ & $\mathbf{2}$ & $\mathbf{5 7}$ & $\mathbf{6 2}$ & $\mathbf{3}$ & $\mathbf{9 3}$ & $\mathbf{1 0 4}$ & $\mathbf{6}$ & $\mathbf{3 2 7}$ \\
\hline \hline
\end{tabular}

Notes and sources: See Appendix Table 2.

\section{Appendix Table 5}

Intergenerational mobility in Figueira da Foz, 1880-1957: a comparison of the social classes of fathers and sons at first marriage (relative and absolute values)

\begin{tabular}{|c|c|c|c|c|c|c|c|c|}
\hline \multirow{2}{*}{$\begin{array}{l}\text { Social class of } \\
\text { the father } \\
1880-1883\end{array}$} & \multicolumn{8}{|c|}{ Social class of the son } \\
\hline & $1+2$ & $3+4+5$ & $6+7$ & 8 & 9 & 11 & $10+12$ & Total $\mathrm{N}$ \\
\hline \multirow{2}{*}{$\begin{array}{l}\text { Higher managers, } \\
\text { higher professionals, } \\
\text { 'owners' }\end{array}$} & 0.0 & 100.0 & 0.0 & 0.0 & 0.0 & 0.0 & 0.0 & 1 \\
\hline & 0.0 & 7.7 & 0.0 & 0.0 & 0.0 & 0.0 & 0.0 & 1.3 \\
\hline \multirow{2}{*}{$\begin{array}{l}\text { Lower managers, } \\
\text { professional and sales }\end{array}$} & 33.3 & 33.3 & 33.3 & 0.0 & 0.0 & 0.0 & 0.0 & 3 \\
\hline & 14.3 & 7.7 & 3.7 & 0.0 & 0.0 & 0.0 & 0.0 & 3.8 \\
\hline \multirow{2}{*}{$\begin{array}{l}\text { Foremen, } \\
\text { medium-skilled workers }\end{array}$} & 0.0 & 0.0 & 37.5 & 0.0 & 37.5 & 25.0 & 0.0 & 8 \\
\hline & 0.0 & 0.0 & 11.1 & 0.0 & 17.6 & 22.2 & 0.0 & 10.0 \\
\hline \multirow[t]{2}{*}{ Farmers (lavradores) } & 25.0 & 0.0 & 0.0 & 0.0 & 25.0 & 0.0 & 50.0 & 4 \\
\hline & 14.3 & 0.0 & 0.0 & 0.0 & 5.9 & 0.0 & 33.3 & 5.0 \\
\hline \multirow[t]{2}{*}{ Lower-skilled workers } & 0.0 & 16.7 & 50.0 & 0.0 & 33.3 & 0.0 & 0.0 & 6 \\
\hline & 0.0 & 7.7 & 11.1 & 0.0 & 11.8 & 0.0 & 0.0 & 7.5 \\
\hline \multirow{6}{*}{$\begin{array}{l}\text { Unskilled workers } \\
\text { (includes 'seamen') } \\
\text { Lower-skilled, } \\
\text { unskilled farm workers } \\
\text { Total } \\
N\end{array}$} & 9.4 & 15.1 & 35.8 & 0.0 & 20.8 & 13.2 & 5.7 & 53 \\
\hline & 71.4 & 61.5 & 70.4 & 0.0 & 64.7 & 77.8 & 50.0 & 66.3 \\
\hline & 0.0 & 40.0 & 20.0 & 20.0 & 0.0 & 0.0 & 20.0 & 5 \\
\hline & 0.0 & 15.4 & 3.7 & 100.0 & 0.0 & 0.0 & 16.7 & 6.3 \\
\hline & 8.8 & 16.3 & 33.8 & 1.3 & 21.3 & 11.3 & 7.5 & 80 \\
\hline & 7 & 13 & 27 & 1 & 17 & 9 & 6 & 80 \\
\hline $1900-1902$ & $1+2$ & $3+4+5$ & $6+7$ & 8 & 9 & 11 & $10+12$ & Total $\mathrm{N}$ \\
\hline \multirow{2}{*}{$\begin{array}{l}\text { Higher managers, } \\
\text { higher professionals, } \\
\text { 'owners' }\end{array}$} & 0.0 & 0.0 & 0.0 & 0.0 & 0.0 & 0.0 & 0.0 & 0 \\
\hline & 0.0 & 0.0 & 0.0 & 0.0 & 0.0 & 0.0 & 0.0 & 0.0 \\
\hline \multirow{2}{*}{$\begin{array}{l}\text { Lower managers, } \\
\text { professional and sales }\end{array}$} & 33.3 & 33.3 & 16.7 & 0.0 & 16.7 & 0.0 & 0.0 & 6 \\
\hline & 25.0 & 6.9 & 1.9 & 0.0 & 3.8 & 0.0 & 0.0 & 4.5 \\
\hline \multirow{4}{*}{$\begin{array}{l}\text { Foremen, } \\
\text { medium-skilled workers } \\
\text { Farmers (lavradores) }\end{array}$} & 0.0 & 28.6 & 57.1 & 0.0 & 14.3 & 0.0 & 0.0 & 7 \\
\hline & 0.0 & 6.9 & 7.5 & 0.0 & 3.8 & 0.0 & 0.0 & 5.3 \\
\hline & 0.0 & 100.0 & 0.0 & 0.0 & 0.0 & 0.0 & 0.0 & 1 \\
\hline & 0.0 & 3.4 & 0.0 & 0.0 & 0.0 & 0.0 & 0.0 & 0.8 \\
\hline
\end{tabular}


Appendix Table 5 (Cont.)

\begin{tabular}{lrrrrrrrr}
\hline Lower-skilled workers & 5.0 & 0.0 & 60.0 & 0.0 & 35.0 & 0.0 & 0.0 & $\mathbf{2 0}$ \\
& 12.5 & 0.0 & 22.6 & 0.0 & 26.9 & 0.0 & 0.0 & 15.2 \\
Unskilled workers & 5.6 & 25.8 & 36.0 & 0.0 & 16.9 & 13.5 & 2.2 & $\mathbf{8 9}$ \\
(includes 'seamen') & 62.5 & 79.3 & 60.4 & 0.0 & 57.7 & 85.7 & 100.0 & 67.4 \\
Lower-skilled, & 0.0 & 11.1 & 44.4 & 0.0 & 22.2 & 22.2 & 0.0 & $\mathbf{9}$ \\
unskilled farm workers & 0.0 & 3.4 & 7.5 & 0.0 & 7.7 & 14.3 & 0.0 & 6.8 \\
Total & 6.1 & 22.0 & 40.2 & 0.0 & 19.7 & 10.6 & 1.5 & $\mathbf{1 3 2}$ \\
$N$ & $\mathbf{8}$ & $\mathbf{2 9}$ & $\mathbf{5 3}$ & $\mathbf{0}$ & $\mathbf{2 6}$ & $\mathbf{1 4}$ & $\mathbf{2}$ & $\mathbf{1 3 2}$ \\
$1911-1913$ & $1+2$ & $3+4+5$ & $6+7$ & 8 & 9 & 11 & $10+12$ & Total $\mathrm{N}$ \\
\hline
\end{tabular}

Higher managers,

\begin{tabular}{|c|c|c|c|c|c|c|c|c|}
\hline \multirow{2}{*}{$\begin{array}{l}\text { higher professionals, } \\
\text { 'owners' }\end{array}$} & 32.1 & 28.6 & 8.9 & 5.4 & 1.8 & 21.4 & 1.8 & 56 \\
\hline & 33.3 & 27.1 & 5.3 & 5.5 & 1.5 & 5.0 & 1.0 & 8.4 \\
\hline \multirow{2}{*}{$\begin{array}{l}\text { Lower managers, } \\
\text { professional and sales }\end{array}$} & 21.9 & 43.8 & 25.0 & 3.1 & 6.3 & 0.0 & 0.0 & 32 \\
\hline & 13.0 & 23.7 & 8.5 & 1.8 & 3.0 & 0.0 & 0.0 & 4.8 \\
\hline \multirow{4}{*}{$\begin{array}{l}\text { Foremen, } \\
\text { medium-skilled workers } \\
\text { Farmers (lavradores) }\end{array}$} & 3.9 & 13.0 & 42.9 & 0.0 & 15.6 & 20.8 & 3.9 & 77 \\
\hline & 5.6 & 16.9 & 35.1 & 0.0 & 18.2 & 6.7 & 3.0 & 11.5 \\
\hline & 6.5 & 2.6 & 5.2 & 41.6 & 2.6 & 37.7 & 3.9 & 77 \\
\hline & 9.3 & 3.4 & 4.3 & 58.2 & 3.0 & 12.1 & 3.0 & 11.5 \\
\hline \multirow[t]{2}{*}{ Lower-skilled workers } & 8.6 & 5.2 & 25.9 & 1.7 & 37.9 & 13.8 & 6.9 & 58 \\
\hline & 9.3 & 5.1 & 16.0 & 1.8 & 33.3 & 3.3 & 4.0 & 8.7 \\
\hline \multirow{6}{*}{$\begin{array}{l}\text { Unskilled workers } \\
\text { (includes 'seamen') } \\
\text { Lower-skilled, } \\
\text { unskilled farm workers } \\
\text { Total } \\
N\end{array}$} & 6.4 & 5.1 & 7.7 & 3.4 & 9.4 & 63.4 & 4.7 & 235 \\
\hline & 27.8 & 20.3 & 19.1 & 14.5 & 33.3 & 62.3 & 11.0 & 35.2 \\
\hline & 0.8 & 1.5 & 8.3 & 7.6 & 3.8 & 18.9 & 59.1 & 132 \\
\hline & 1.9 & 3.4 & 11.7 & 18.2 & 7.6 & 10.5 & 78.0 & 19.8 \\
\hline & 8.1 & 8.8 & 14.1 & 8.2 & 9.9 & 35.8 & 15.0 & 667 \\
\hline & 54 & 59 & 94 & 55 & 66 & 239 & 100 & 667 \\
\hline $1925-1927$ & $1+2$ & $3+4+5$ & $6+7$ & 8 & 9 & 11 & $10+12$ & Total $\mathrm{N}$ \\
\hline \multirow{2}{*}{$\begin{array}{l}\text { Higher managers, } \\
\text { higher professionals, } \\
\text { 'owners' }\end{array}$} & 17.8 & 22.2 & 10.0 & 5.6 & 8.9 & 34.4 & 1.1 & 90 \\
\hline & 55.2 & 27.4 & 8.7 & 8.1 & 10.4 & 8.8 & 1.8 & 12.0 \\
\hline \multirow{2}{*}{$\begin{array}{l}\text { Lower managers, } \\
\text { professional and sales }\end{array}$} & 7.4 & 59.3 & 25.9 & 0.0 & 3.7 & 0.0 & 3.7 & 27 \\
\hline & 6.9 & 21.9 & 6.7 & 0.0 & 1.3 & 0.0 & 1.8 & 3.6 \\
\hline \multirow{4}{*}{$\begin{array}{l}\text { Foremen, } \\
\text { Medium-skilled workers } \\
\text { Farmers (lavradores) }\end{array}$} & 1.5 & 11.9 & 52.2 & 1.5 & 13.4 & 19.4 & 0.0 & 67 \\
\hline & 3.4 & 11.0 & 33.7 & 1.6 & 11.7 & 3.7 & 0.0 & 8.9 \\
\hline & 6.6 & 1.6 & 8.2 & 29.5 & 3.3 & 47.5 & 3.3 & 61 \\
\hline & 13.8 & 1.4 & 4.8 & 29.0 & 2.6 & 8.2 & 3.6 & 8.1 \\
\hline \multirow[t]{2}{*}{ Lower-skilled workers } & 4.5 & 18.2 & 15.9 & 4.5 & 31.8 & 22.7 & 2.3 & 44 \\
\hline & 6.9 & 11.0 & 6.7 & 3.2 & 18.2 & 2.8 & 1.8 & 5.9 \\
\hline \multirow{4}{*}{$\begin{array}{l}\text { Unskilled workers } \\
\text { (includes 'seamen') } \\
\text { Lower-skilled, } \\
\text { unskilled farm workers }\end{array}$} & 1.0 & 4.6 & 8.6 & 8.6 & 9.8 & 61.4 & 6.0 & 417 \\
\hline & 13.8 & 26.0 & 34.6 & 58.1 & 53.2 & 72.7 & 45.5 & 55.5 \\
\hline & 0.0 & 2.2 & 10.9 & 0.0 & 4.3 & 28.3 & 54.3 & 46 \\
\hline & 0.0 & 1.4 & 4.8 & 0.0 & 2.6 & 3.7 & 45.5 & 6.1 \\
\hline \multirow{2}{*}{$\begin{array}{l}\text { Total } \\
N\end{array}$} & 3.9 & 9.7 & 13.8 & 8.2 & 10.2 & 46.8 & 7.3 & 752 \\
\hline & 29 & 73 & 104 & 62 & 77 & 352 & 55 & 752 \\
\hline
\end{tabular}


Appendix Table 5 (Cont.)

\begin{tabular}{|c|c|c|c|c|c|c|c|c|}
\hline $1935-1937$ & $1+2$ & $3+4+5$ & $6+7$ & 8 & 9 & 11 & $10+12$ & Total $\mathrm{N}$ \\
\hline \multicolumn{9}{|l|}{ Higher managers, } \\
\hline $\begin{array}{l}\text { higher professionals, } \\
\text { 'owners' }\end{array}$ & $\begin{array}{l}15.9 \\
70.0\end{array}$ & $\begin{array}{l}21.6 \\
20.7\end{array}$ & $\begin{array}{l}0.8 \\
6.0\end{array}$ & $\begin{array}{r}11.4 \\
9.1\end{array}$ & 12.7 & $\begin{array}{r}20.4 \\
9.8\end{array}$ & 4.9 & 11.9 \\
\hline \multirow{2}{*}{$\begin{array}{l}\text { Lower managers, } \\
\text { professional and sales }\end{array}$} & 3.3 & 56.7 & 10.0 & 3.3 & 11.7 & 11.7 & 3.3 & 60 \\
\hline & 10.0 & 37.0 & 6.0 & 1.8 & 8.9 & 2.7 & 2.4 & 8.1 \\
\hline \multirow{2}{*}{$\begin{array}{l}\text { Foremen, } \\
\text { medium-skilled workers }\end{array}$} & 1.5 & 12.1 & 48.5 & 3.0 & 19.7 & 12.1 & 3.0 & 66 \\
\hline & 5.0 & 8.7 & 32.0 & 1.8 & 16.5 & 3.1 & 2.4 & 8.9 \\
\hline \multirow[t]{2}{*}{ Farmers (lavradores) } & 2.0 & 5.1 & 13.1 & 42.4 & 6.1 & 24.2 & 7.1 & 99 \\
\hline & 10.0 & 5.4 & 13.0 & 38.2 & 7.6 & 9.4 & 8.5 & 13.4 \\
\hline \multirow[t]{2}{*}{ Lower-skilled workers } & 0.0 & 22.2 & 20.0 & 11.1 & 33.3 & 11.1 & 2.2 & 45 \\
\hline & 0.0 & 10.9 & 9.0 & 4.5 & 19.0 & 2.0 & 1.2 & 6.1 \\
\hline \multirow{6}{*}{$\begin{array}{l}\text { Unskilled workers } \\
\text { (includes 'seamen') } \\
\text { Lower-skilled, } \\
\text { unskilled farm workers } \\
\text { Total } \\
N\end{array}$} & 0.3 & 4.4 & 9.6 & 13.1 & 6.7 & 51.5 & 14.5 & 344 \\
\hline & 5.0 & 16.3 & 33.0 & 40.9 & 29.1 & 69.1 & 61.0 & 46.5 \\
\hline & 0.0 & 2.7 & 2.7 & 10.8 & 13.5 & 27.0 & 43.2 & 37 \\
\hline & 0.0 & 1.1 & 1.0 & 3.6 & 6.3 & 3.9 & 19.5 & 5.0 \\
\hline & 2.7 & 12.4 & 13.5 & 14.9 & 10.7 & 34.6 & 11.1 & 739 \\
\hline & 20 & 92 & 100 & 110 & 79 & 256 & 82 & 739 \\
\hline $1955-1957$ & $1+2$ & $3+4+5$ & $6+7$ & 8 & 9 & 11 & $10+12$ & Total $\mathrm{N}$ \\
\hline \multicolumn{9}{|l|}{ Higher managers, } \\
\hline \multirow{2}{*}{$\begin{array}{l}\text { higher professionals, } \\
\text { 'owners' }\end{array}$} & 28.6 & 28.6 & 7.1 & 7.1 & 21.4 & 7.1 & 0.0 & 14 \\
\hline & 57.1 & 16.0 & 4.2 & 12.5 & 15.8 & 4.0 & 0.0 & 11.3 \\
\hline \multirow{2}{*}{$\begin{array}{l}\text { Lower managers, } \\
\text { professional and sales }\end{array}$} & 15.8 & 42.1 & 21.1 & 0.0 & 10.5 & 5.3 & 5.3 & 19 \\
\hline & 42.9 & 32.0 & 16.7 & 0.0 & 10.5 & 4.0 & 6.3 & 15.3 \\
\hline \multirow{2}{*}{$\begin{array}{l}\text { Foremen, } \\
\text { medium-skilled workers }\end{array}$} & 0.0 & 16.7 & 55.6 & 0.0 & 22.2 & 5.6 & 0.0 & 18 \\
\hline & 0.0 & 12.0 & 41.7 & 0.0 & 21.1 & 4.0 & 0.0 & 14.5 \\
\hline \multirow[t]{2}{*}{ Farmers (lavradores) } & 0.0 & 27.3 & 18.2 & 22.7 & 13.6 & 9.1 & 9.1 & 22 \\
\hline & 0.0 & 24.0 & 16.7 & 62.5 & 15.8 & 8.0 & 12.5 & 17.7 \\
\hline \multirow[t]{2}{*}{ Lower-skilled workers } & 0.0 & 11.8 & 17.6 & 5.9 & 35.3 & 11.8 & 17.6 & 17 \\
\hline & 0.0 & 8.0 & 12.5 & 12.5 & 31.6 & 8.0 & 18.8 & 13.7 \\
\hline Unskilled workers & 0.0 & 9.1 & 4.5 & 4.5 & 0.0 & 54.5 & 27.3 & 22 \\
\hline (includes 'seamen') & 0.0 & 8.0 & 4.2 & 12.5 & 0.0 & 48.0 & 37.5 & 17.7 \\
\hline Lower-skilled, & 0.0 & 0.0 & 8.3 & 0.0 & 8.3 & 50.0 & 33.3 & 12 \\
\hline unskilled farm workers & 0.0 & 0.0 & 4.2 & 0.0 & 5.3 & 24.0 & 25.0 & 9.7 \\
\hline Total & 5.6 & 20.2 & 19.4 & 6.5 & 15.3 & 20.2 & 12.9 & 124 \\
\hline$N$ & 7 & 25 & 24 & 8 & 19 & 25 & 16 & 124 \\
\hline
\end{tabular}

Notes and sources: See Appendix Table 2.

\section{ACKNOWLEDGEMENTS}

The article presents some of the findings of the 'Social mobility in Portugal during the nineteenth and twentieth centuries: a historical study (1850-1960)' project, which is financed partly by the Portuguese Science Foundation. We are grateful to Rui Cascão for allowing us to use his transcripts of marriage certificates for Figueira da Foz and Buarcos (1880-1900). 
We would also like to thank the referees and Marco van Leeuwen for their comments and suggestions on an earlier version of the text.

\section{ENDNOTES}

1 For a detailed account of the historical and sociological studies on social mobility in Portugal during the nineteenth and twentieth centuries, see Hélder A. Fonseca and P. Guimarães, 'Mobilidade social intergeracional em Portugal 1911-1957: os exemplos de Évora e Setúbal', in Livro de homenagem a Miriam Halpern Pereira (Lisbon, 2005).

2 Hélder Adegar Fonseca, $O$ Alentejo no século XIX: economia e atitudes económicas (Lisbon, 1996); P. Guimarães, 'O Alentejo e o desenvolvimento mineiro durante da Regeneração', in Miguel Rego ed., Mineração no Baixo Alentejo, Vol. I (Castro Verde, Câmara Municipal, 1996), 114-29.

3 C. Castelo, Passagens para África: o povoamento de Angola e Moçambique com naturais da metrópole 1920-1974 (Porto, 2007).

4 Pedro Lains and Álvaro Ferreira da Silva eds., História económica de Portugal, Vol. III: $O$ século $X X$ (Lisbon, 2005).

5 While the work of E. Estanque and J. Mendes, Classes e desigualdades sociais em Portugal (Porto, 1997), was inspired by Erik Olin Wright, Class counts: comparative studies in class analysis (Cambridge, 1997), M. V. Cabral, 'Mobilidade social e atitudes de classe em Portugal', Análise Social, 146-7 (1998), 381-414, is closer to Goldthorpe's pragmatic approach to social stratification. See R. Erikson and J. H. Goldthorpe, The constant flux: a study of class mobility in industrial societies (Oxford, 1993).

6 The marriage registers from before 1911 (parish records) are available to the public in the Historical Archives of the Districts of Évora, of Setúbal and of Figueira da Foz. The registers from after 1911 are kept in the archives of the Conservatórias do Registo Civil in Évora, Setúbal, Figueira da Foz and Barreiro. The Historical Sample of Portuguese Social Mobility (HSPSM) was built with data gathered from those sources and will be available soon.

7 PACO (Project for the Analysis and Classification of Occupations in Portugal) was coordinated by Nuno L. Madureira and adopted closely the principles outlined in M. H. D. van Leeuwen et al., Historical Standard Coding of Occupations: final coding principles with examples from Norway and Germany (HISMA Occasional Papers \& Documents Series, 4) (Berlin, 1999). See Nuno L. Madureira coord., 1000 ocupações históricas: projecto para a análise e classificação das ocupaçoes/Historical International Standard of Classification of Occupations, PACO/HISCO (Lisbon, 2000).

8 Miles Andrew and David Vincent eds., Building European society: occupational change and social mobility in Europe 1840-1940 (Manchester, 1993), 3.

9 Marco H. D. van Leeuwen, Ineke Maas, and Andrew Miles, HISCO: Historical International Standard Classification of Occupations (Leuven, 2002), 26 (and http:// historyofwork.iisg.nl/); M.H.D. van Leeuwen, I. Maas, and A. Miles, 'Creating an Historical International Standard Classification of Occupations (HISCO): an exercise in multi-national, interdisciplinary co-operation', Historical Methods 37 (2004), 186-97; Madureira coord., 1000 ocupações históricas. Occupations were classified into HISCLASS using the following recode job: I. Maas and Marco H. D. van Leeuwen, hisco_hisclass12a_@inc; see http://historyofwork.iisg.nl/. See also Ineke Maas and Marco H. D. van Leeuwen, 'Total and relative endogamy by social origin: a first international comparison of changes in marriage choices during the nineteenth century', 
International Review of Social History 50 (2005), 275-95, and Marco H. D. van Leeuwen and I. Maas, 'A short note on Hisclass', November 2005, available at http:// historyofwork.iisg.nl/docs/hisclass-brief.doc.

10 Unfortunately, from the 1960s onward the occupations of the parents of the bridegrooms were not registered in the marriage records.

11 Frédéric Vidal, Les habitants d'Alcântara: histoire social d'un quartier de Lisbonne au début du $20^{e}$ siècle (Villeneuve d'Ascq, 2006).

12 Michael B. Katz, 'Occupational classification in history', Journal of Interdisciplinary History 3 (1972), 63-88; Margo Anderson, '(Only) white men have class: reflections on early 19th-century occupational classification', Work and Occupations: An International Sociological Journal 21 (1994), 5-32; Andrew Miles, Social mobility in nineteenth- and early twentieth-century England (London, 1999), 18-20.

13 Such as 'worker' (26.5 per cent); 'seaman' and 'fisherman' (7.4 per cent); 'rural worker' and 'day-labourer' ( 4.3 per cent); 'farmer' ( 3.6 per cent); 'carpenter' ( 2.6 per cent); ' mason' ( 2.3 per cent); blacksmith ( 2.5 per cent $)$; 'trade employee' ( 2.7 per cent); 'office employee' (1.8 per cent); 'trader' (1.9 per cent); 'owner' (1.7 per cent); 'cork worker' (1.4 per cent); and 'shoemaker' (1.3 per cent).

14 João Freire, Anarquistas e operários: ideologia, oficio e práticas sociais: o Anarquismo e o Operariado em Portugal, 1900-1940 (Lisbon, 1992).

15 Ana Nunes de Almeida, A fábrica e a família: famílias operárias no Barreiro (Barreiro, 1993), 146-7.

16 Hélder A. Fonseca and Paulo Guimarães, 'Os catalães da Azaruja: ofício, família e mobilidade social (1845-1914)', in Jordi Nadal ed., Nissagues gironines en la indústria surera portuguesa (1845-1985) (Barcelona, 2005); Maria Filomena Mónica ed., Os vidreiros da Marinha Grande: actas sindicais (1919-45) (Lisbon, n.d.); Nunes de Almeida, A fábrica e a família; Conceição Martins and Nuno Monteiro eds., História do trabalho e das ocupações, Vol. III : A agricultura: dicionário (Lisbon, 2002), 339-42.

17 José Pedro Sousa Dias, A farmácia em Portugal: uma introdução à sua história (Lisbon, 1994).

18 P. Guimarães, Elites e indústria no Alentejo: 1890-1960 (Évora, 2006), chapter 6.

19 Fonseca, O Alentejo no século XIX; José Vicente Serrão, 'Lavrador', in Martins and Monteiro eds., História do trabalho e das ocupações, Vol. III, 64-76.

20 Adelino Mendes and António Barros, O Algarve e Setúbal (Lisbon, 1916); Maria Conceição Quintas, Setúbal: economia, sociedade e cultura operária (1880-1930) (Lisbon, 1998), 270-4; Inês Amorim ed., História do trabalho e das ocupações, Vol. II: Pescas (Lisbon, 2001).

21 Rui Cascão, Figueira da Foz e Buarcos 1861-1910 (Figueira da Foz, 1998), 457.

22 Hélder Adegar Fonseca, 'O perfil social da "elite censitária" no sul de Portugal: Alentejo, século XIX', Ayer 48 (2002), 207-10.

23 Jorge Pedreira, 'Os negociantes de Lisboa na segunda metade do século XVIII: padrões de recrutamento e percursos sociais', Análise Social 116-17 (1992), 407-40; Fonseca, 'O perfil social da "elite censitária", 190-5; Filomena Mónica, 'Capitalistas e industriais (1870-1914)', Análise Social 99 (1987), 818-63.

24 Ana Silvia Scott, Familias, formas de união e reprodução social no noroeste português (séculos XVIII e XIX) (Guimarães, 1999), 349-98; Miguel Monteiro, Migrantes, emigrantes e brasileiros (1834-1926) (Fafe, 2000), 247-318.

25 A. P. Tavares de Almeida, 'A construção do estado liberal: elite política e burocracia na “Regeneração” (1851-1890)' (unpublished Ph.D thesis, University of Lisbon, 1995), 268-319. 
26 Miguel Monteiro, A emigração como mecanismo de mobilidade social em Portugal: o exemplo de Fafe (1834-1926) (XVII Encontro da APHES, papers) (Lisbon, 2007); available at http://aphes.fe.unl.pt/aphescom.html.

27 Helena Alves, Minas de S. Domingos: génese, formação social e identidade mineira (Mértola, 1997), 128-30; Paulo Guimarães, Indústria e conflito no meio rural: os mineiros alentejanos (1858-1938) (Lisbon, 2001), 115-77; Paulo Guimarães, 'Recrutamento, mobilidade e demografia na mina de S. Domingos, Alentejo (1860-1900)', Revista de Demografia histórica Histórica XXIII (2005), 21-70.

28 Manuel Villaverde Cabral, O operariado nas vésperas da república (1909-1910) (Lisbon, 1977), 92-3; Pedro de Freitas, Memórias dum ferroviário (Lisbon, 1954).

29 Filomena Mónica ed., Os vidreiros da Marinha Grande, iv; Nunes de Almeida, A fábrica e a família, 153-7 and 174.

30 António Mendes Correia, 'Estrutura social do povo português', Revista do Centro de Estudos Demográficos 8 (1953), 123.

31 Luciano Amaral, 'O trabalho', in Lains and Ferreira da Silva eds., História económica de Portugal, 68.

32 Rui Machete, 'A origem social dos estudantes portugueses', Análise Social 22-4 (1968), 241.

33 The 'upper-middle class' are 'higher managers and administrative workers, mediumskilled liberal professions'; the 'upper class' are the 'higher-skilled liberal professions, and higher managers and administrative staff working for major corporations and the state'. See Adérito Sedas Nunes and J. David Miranda, 'A composição social da população portuguesa-alguns aspectos e implicações', Análise Social 27-8 (1969), 333-81.

34 Machete, 'A origem social dos estudantes portugueses', 229-30; Adérito Sedas Nunes, 'A População Universitária portuguesa: análise preliminar', Análise Social 22-4 (1968), 327-35, 332.

35 In 1979, 80 per cent of those managers had higher qualifications. See Hermano Carmo, 'Os dirigentes da administração em Portugal', Estudos Políticos e Sociais V (1987), 319.

36 Guimarães, Elites e industria no Alentejo, 359-93.

37 Manuel de Mello, Inquérito á estrutura social do concelho de espinho, 1942 (Lisbon, 1943), 28. See also, for the industrial footwear sector (S. João da Madeira), Elísio Estanque, Entre a fábrica e a comunidade: subjectividades e práticas de classe no operariado do Calcado (Porto, 2000), 210-20.

38 This universe was analysed by Makler in 1964 using a sample of 306 interviewees, the oldest of whom was born around 1910. The majority of those interviewed were sons of industrial entrepreneurs ( 43.2 per cent), with traders ( 14.5 per cent), farmers and landowners ( 9.6 per cent), the liberal professions (13.2 per cent), public servants and the military ( 8.9 per cent), office employees (3.6 per cent), skilled or unskilled workers $(2.0$ per cent), and rural workers ( 0.7 per cent) accounting for the rest. It is also remarkable that 32 per cent of those leaders came from 'small' or 'medium-sized' industrial, commercial, or agricultural firms. See Harry Mark Makler, $A$ 'elite' industrial portuguesa (Lisbon, 1969), 59.

39 This picture is confirmed by empirical observations on, for example, the metalworkers of CUF, the main industrial company in Barreiro: 'workers not specialized and craft workers [the metalworkers] had two distinctive and opposed sets of working conditions. As time passed, and as the result of intermarriage within the industrial community, those two groups moved closer to one other [in terms of wage differentiation] ... In the 1940s, a CUF craft worker was, almost without exception, the son of a former worker there.' See Nunes de Almeida, A fábrica e a familia, 153. 
40 In 1961, when the Colonial War broke out and one year after the country joined EFTA, a researcher at the Portuguese Industrial Association surveyed the labour motives of 370 workers (male and female) from different generations, drawn from Lisbon's various metalworking firms (which employed between 11 and 400 workers). The survey found that 81 per cent of the male specialized workers born between 1916 and 1947 said that they began working when they were aged between 5 and 14 ( 84 per cent), with 67 per cent who began working when aged between 11 and 14 . Only 58.8 per cent of those interviewed began their working life in the industrial sector, and only 29.5 per cent of their fathers were industrial workers. See Maria Susana de Almeida, Motivações no trabalho (Lisbon, 1962), 19-98.

41 For the methodology and topographic models used here see Marco H. D. van Leeuwen and Ineke Maas, 'Log-linear analysis of changes in mobility patterns', Historical Methods 24 (1991), 65-79, and also Ineke Maas and Marco H. D. van Leeuwen, 'Industrialization and intergenerational Mobility in Sweden', Acta Sociologica 45 (2002), 179-94. Also useful was A. Cobalti, Lo studio della mobilitá (Rome, 1995), chapters 3 and 7. We also used LEM: log-linear and event history analysis with missing data, version 1.0, software developed by Jeroen Vermunt at Tilburg University, The Netherlands.

42 Manuel Villaverde Cabral, 'Classes sociais', in António Barreto and Filomena Mónica eds., Dicionário de história de Portugal, Vol. VII (Porto, 1999), 328-36. Mobility tables for the four different regional contexts, by period cohort, are provided in the appendix (see Tables 5a, 5b, 5c, and 5d).

43 Hartmut Kaelble, 'Social mobility', in Peter Stearns ed., Encyclopedia of European social history from 1350 to 2000, Vol. III (New York, 2001), 113-17. 